\title{
Process-based modelling of the impacts of land use change on the water balance in the Cerrado biome (Rio das Mortes, Brazil)
}

Article

Published Version

Meister, S., Nobrega, R. L.B., Rieger, W., Wolf, R. and Gerold, G. (2017) Process-based modelling of the impacts of land use change on the water balance in the Cerrado biome (Rio das Mortes, Brazil). Erdkunde : Archive for Scientific Geography, 71 (3). pp. 241-266. ISSN 0014-0015 doi: https://doi.org/10.3112/erdkunde.2017.03.06 Available at https://centaur.reading.ac.uk/75432/

It is advisable to refer to the publisher's version if you intend to cite from the work. See Guidance on citing.

Published version at: https://www.erdkunde.uni-bonn.de/archive/2017/process-based-modelling-of-the-impacts-ofland-use-change-on-the-water-balance-in-the-cerrado-biome-rio-das-mortes-brazil

To link to this article DOI: http://dx.doi.org/10.3112/erdkunde.2017.03.06

Publisher: Universitaet Bonn

All outputs in CentAUR are protected by Intellectual Property Rights law, including copyright law. Copyright and IPR is retained by the creators or other copyright holders. Terms and conditions for use of this material are defined in the End User Agreement. 


\section{www.reading.ac.uk/centaur}

\section{CentAUR}

Central Archive at the University of Reading

Reading's research outputs online 


\title{
PROCESS-BASED MODELLING OF THE IMPACTS OF LAND USE CHANGE ON THE WATER BALANCE IN THE CERRADO BIOME (RIO DAS MORTES, BRAZIL)
}

\author{
Sarina Meister, Rodolfo L. B. Nobrega, Wolfgang Rieger, Ronja Wolf and Gerhard Gerold
}

With 12 figures and 8 tables

Received 14 January 2017 • Accepted 3 July 2017

\begin{abstract}
Summary: Since the 1980s, the state of Mato Grosso, Brazil, exhibits high rates of Cerrado conversion in favour of soybean expansion and cattle ranching. This conversion process becomes obvious in the upper Rio das Mortes macro-catchment. The objective of this study was to assess the influence of future land use changes on the discharge dynamics of the Rio das Mortes River. A single catchment approach was applied with the physically-based water balance simulation model WaSiM 8.5.0 (SCHULLA and JASPER 2007) to simulate land use scenarios. In Scenario 1, only small pasture sites $\left(<1 \mathrm{~km}^{2}\right)$ were converted into the respective land use type surrounding them (i.e. cropland or Cerrado vegetation), whereas in Scenario 2 all pasture sites were converted into cropland and all Cerrado patches were then transformed into pastures. The WaSiM model was calibrated and validated based on discharge data measured at two gauging stations, achieving Nash-Sutcliffe coefficients of 0.81 (calibration) and 0.68 (validation). Main problems in modelling arise because of scarce spatial distributed data on subsurface parameter and vegetation parameter (Cerrado biome). Therefore, the use of the numerical groundwater model and manifold calibration runs were essential in this modelling approach to allow the simulation of the high levels of baseflow during the dry season and the transition from the dry to the wet season. The immediate rise of the baseflow in response to the increasing precipitation at beginning of the rainy season is a result of high soil hydraulic conductivity and groundwater recharge. These soil characteristics apparently persist on newly-created pasture and cropland sites, which still exhibit high ksat values after deforestation. Simulated evapotranspiration is comparable to literature values (Eddy flux measurements, MODIS-EVI calculation) and recently done paired micro-catchment studies in this catchment. The scenario analysis indicates that there are only small differences in runoff volume, which is directly related to the precipitation changes. In the scenario 2, groundwater recharge and base flow increase, whereas surface runoff does not. Therefore, the ongoing land use intensification with pasture conversion to cropland, remaining high infiltration and slight increase of evapotranspiration may not change runoff volume and discharge characteristics.
\end{abstract}

Zusammenfassung: Seit den 1980iger Jahren erfolgte im Bundesstaat Mato Grosso (Brasilien) eine weitflächige Umwandlung des Cerrado (Baumsavanne) in Rinderweiden und Ackerland (Sojaanbau). Das Rio das Mortes Einzugsgebiet ist geprägt von diesem Konversionsprozess. Ziel der Studie war die Analyse und Simulation des zukünftigen Landnutzungswandels auf das Abflussgeschehen des Rio das Mortes. Dafür wurde das physikalisch basierte Wasserhaushaltsmodell WaSiM 8.5.0 (Schulla and JASPer 2007) für das Makroeinzugsgebiet des Rio das Mortes kalibriert und zur Simulation entsprechender Landnutzungsszenarien eingesetzt. In Szenario 1 erfolgte eine Konversion kleiner Weideflächen $(<1 \mathrm{~km} 2)$ in den umgebenden Landnutzungstyp (Cerrado-Vegetation oder Ackerland), während im Szenario 2 alle Weideflächen in Ackerland und alle Cerradoflächen außerhalb der Schutzgebiete in Weideflächen umgewandelt wurden. Die Kalibrierung und Validierung des WaSiM-Modells erfolgte anhand der Abflussdaten zweier Pegelstationen mit Kalibrations- und Validationskoeffizienten von 0,81 und 0,68 nach Nash-Sutcliffe. Innerhalb der Modellparametrisierung traten Probleme aufgrund der unzureichenden Datengrundlage im Bereich des Grundwasser und der Vegetation (Cerrado-Biom) auf. Daher waren für den Modelleinsatz die Kopplung mit dem numerischen Grundwassermodell und zahlreiche Kalibrationsläufe nötig, um den hohen Basisabfluss und den Jahreszeiteneinfluss mit Trocken- und Regenzeit in Volumen und zeitlichem Verlauf zu simulieren. Ein schneller Anstieg des Basisabflusses mit der Niederschlagszunahme zu Beginn der Regenzeit ist ein Ergebnis hoher hydraulischer Leitfähigkeiten und einer hohen Grundwasserneubildungsrate, die auch nach Entwaldung auf den Weide- und Ackerflächen mit hohen ksat-Werten weiter bestehen bleibt. In den Landnutzungsszenarien verändert sich der maßgeblich vom Niederschlagsgeschehen abhängige Abfluss kaum. In Szenario 2 erhöhen sich die Grundwasserneubildungsrate und der Basisabfluss, während der Oberflächenabfluss nicht ansteigt. Mit der fortschreitenden Landnutzungsintensivierung durch Umwandlung von Weideland in Ackerland, in der Regel mit no-tillage Systemen, bleibt die hohe Infiltrationsrate mit einem leichten Anstieg der Verdunstung bestehen, so dass Abflussvolumen und Abflusscharakteristik sich wahrscheinlich kaum ändern werden.

Keywords: land use change, water balance modelling, deforestation, WaSiM, Cerrado, Brazil 


\section{Introduction}

The southern fringe of the Amazon rainforest and the Cerrado Biome in Brazil are hotspots of forest conversion with ongoing land use change since the 1980s. Large deforestation of primary forest into huge areas of cropland and pastures have caused international concern and discussion on the role of the Amazon in the context of global climate change ("fate of the Amazon") and global carbon cycle (Malhi et al. 2008; NePSTAD et al. 2009; Fearnside et al. 2009). Consequently, Lovejoy (2007) pointed out that the "Bistability of Amazonian Forest" is a critical threshold in the Earth system. During the agro-industrial expansion phase (late 1990s until 2004), large scale expansion of soy and other mechanized crops accompanied by an intensification of cattle production - driven by global market conditions and technological advances - took place in the southeastern part of Amazon (NePSTAD et al. 2014). In the state of Mato Grosso, more than half of the forest clearing happened during this phase. The natural vegetation in Mato Grosso is dominated by Cerrado - a semiarid sclerophyllous shrub vegetation intersected with narrow strips of gallery forest buffers along streams. The state promotes high rates of Cerrado conversion in vast areas of its territory in order to maintain its leading position in soybean and cattle production $(27 \%$ of the national soybean production and $14 \%$ of the "the nation's total livestock" of 2010) (DeFries et al. 2013). Approximately 50\% of the original 2 million $\mathrm{km}^{2}$ of the Cerrado area is under agricultural use (BEUCHLE et al. 2015), compromising about $80 \%$ of the primary Cerrado vegetation. The conversion of Cerrado vegetation is likely to continue as a dominant process of land use change in this region (LAPOLA et al. 2014). Most of the former Cerrado pasture areas were established after the 1970s (LiLIENFEIN et al. 2003:1195).

Since forests play a main role in the regulation of the regional water balance, deforestation and land use change have also been intensively discussed for the Amazon River Basins (Lima et al. 2014). The hydrological impacts of land use changes affect both water quantity and quality. The former includes significant changes in runoff characteristics, discharge routing and velocity, water yield, groundwater recharge, retention, storage and infiltration capacity of soils as well as changes in precipitation and evaporation rates (GRIP et al. 2005; AYLWARD 2005; Bonell 2005). HunKE et al. (2014) highlighted that water and soil degradation are mainly because of intensive agri- cultural use in Mato Grosso. Where soil infiltration characteristics and regional precipitation remain unchanged, deforestation leads to an increase in river discharge and flooding risks due to a reduced evapotranspiration (Brujjnzeel 2004). Paired catchment studies in the Western Amazon (Germer et al. 2009) showed that conversion of forest to pasture results in increased frequency and volume of overland flow. Simulations without climate response to deforestation in Southwestern Amazon show an increase in river discharge proportional to the area deforested in each basin (Lima et al. 2014), but for large catchments feedback processes of the regional water cycle can result in a decrease of precipitation (PIAO et al. 2007). Therefore, total discharge may also possibly decrease, although evapotranspiration also decreases. By using the IBIS land surface model coupled with a Terrestrial Hydrology Model (THMB), LiMA et al. (2014) generated deforestation scenarios for the basin areas of Juruá, Purus and Madeira rivers ( $\geq 21 \%$ deforestation). In the process, they showed a decrease of precipitation by $8-15 \%$, which resulted in a total river discharge decrease for Juruá and Purus rivers, whereas the discharge for Madeira River increased. Such contradictory results are also found when simulating BAU-scenarios (until 2050) for the entire Amazon Basin with different General Circulation Models (GCM). The calculated changes range from $+1 \mathrm{~mm}$ $\mathrm{d}^{-1}$ to $-1 \mathrm{~mm} \mathrm{~d}^{-1}$ for precipitation and $-0.5 \mathrm{~mm} \mathrm{~d}^{-1}$ (CCMS-model) to $+0.92 \mathrm{~mm} \mathrm{~d}^{-1}$ (ECHAM4) for river discharge (D'Almeida et al. 2007).

However, consequences of deforestation on the water balance and river discharge vary within river basins, and their characteristics and prediction with hydrological models are also scale-dependent (GEROLD 2012, Lima et al. 2014). Since land use is a key factor controlling the hydrological behaviour of a catchment, accelerated agricultural activity on former forest sites results in a change of hydraulic soil properties, which cause changes in discharge generation and discharge components. The magnitude and duration of land use change effects on stream flows is influenced by soil properties, morphology, geology, rainfall characteristics, type of vegetation, and land use and cover established after deforestation (BIRKINSHAW et al. 2011).

In summary, previous findings on the impact of land use and vegetation cover change on the water balance are often contradictory. Hence, process-based hydrological models validated with field data are considered a suitable tool for identifying and quantifying the influence of deforestation and subsequent agricultural land use on hydrologi- 
cal processes reliably (ELFERT 2010; Costa 2005) and for deriving conclusions for sustainable future land management. For an effective model calibration detailed data are necessary, but for the Cerrado biome the problem of scarce data availability for spatial discretization, model parameterization and use of long continuous meteorological and hydrological data arises. Given this background, the main objective of this study is to assess the influence of changes in land use on the temporal dynamics of river discharge in the Cerrado biome with a macroscale watershed in Mato Grosso State, Brazil. To simulate consequences of land use change on the water balance the physically based model WaSiM 8.5.0 (SCHUlla AND JASPER 2007) was used for the Rio das Mortes macro-catchment. This is the first time WaSiM was applied for Southern Amazon. The specific aims of this study are:

- to set up and adjust the WaSiM model via parameterisation and calibration to the Cerrado catchment characteristics for the current situation based on a scarce data availability and;

- to analyse the influence of future land use and land cover (LULC) changes on the water balance and discharge dynamics via scenario simulation.

\section{Macro-catchment description}

The study was conducted in the upper Rio das Mortes watershed (Fig. 1), located in Mato Grosso State, Brazil. The watershed is located between $53^{\circ}$ $45^{\prime}$ and $55^{\circ} 30^{\prime} \mathrm{W}$, and $14^{\circ} 45^{\prime}$ and $16^{\circ} 00^{\prime} \mathrm{S}$, and drains an area of $17,700 \mathrm{~km}^{2}$. The study area is in the western part of the Central Brazilian Plateau. The relief in this area is predominantly flat to very gently undulating and the elevation varies from $336 \mathrm{~m}$ in the lowlands along the river network and the gallery forests to $908 \mathrm{~m}$ with slopes predominantly in the $1-5 \%$ range. On the deeply weathered Central Brazilian Plateau, the soils, originating from tertiary sediments, are old, well-drained, and strongly depleted (Montgomery and Askew 1983; Landon 1984; EMBrapa 2012). The main soil types (Brazilian soil classification) in the watershed are Latossolo vermelhoamarelho (haplic Ferralsols - WRB, Oxisols - USDA), Latossolo vermelho-escuro (rhodic Ferralsols - WRB, Oxisols - USDA) and Areias Quartrosas (Arenosol/ Entisol - WRB/USDA) (Projeto RADAMBRASIL; Embrapa 2012; Fig. 2). Together, they cover nearly $88 \%$ of the macro-catchment. These soils exhibit an elevated acidity, high levels of iron and aluminium

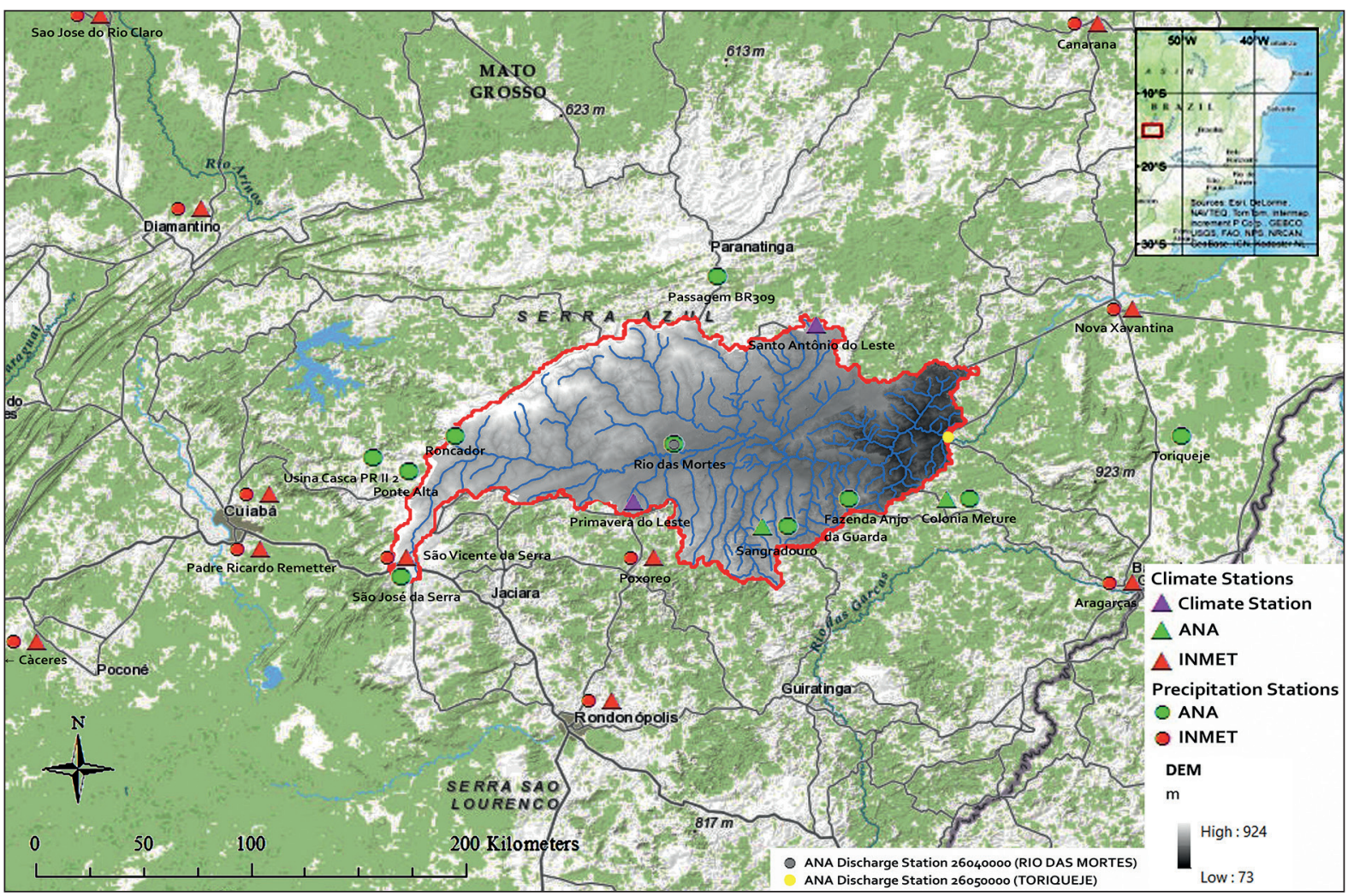

Fig. 1: The Upper Rio das Mortes catchment with climate, precipitation and discharge stations (after GuzHA et al. 2013; WOLF 2016) 


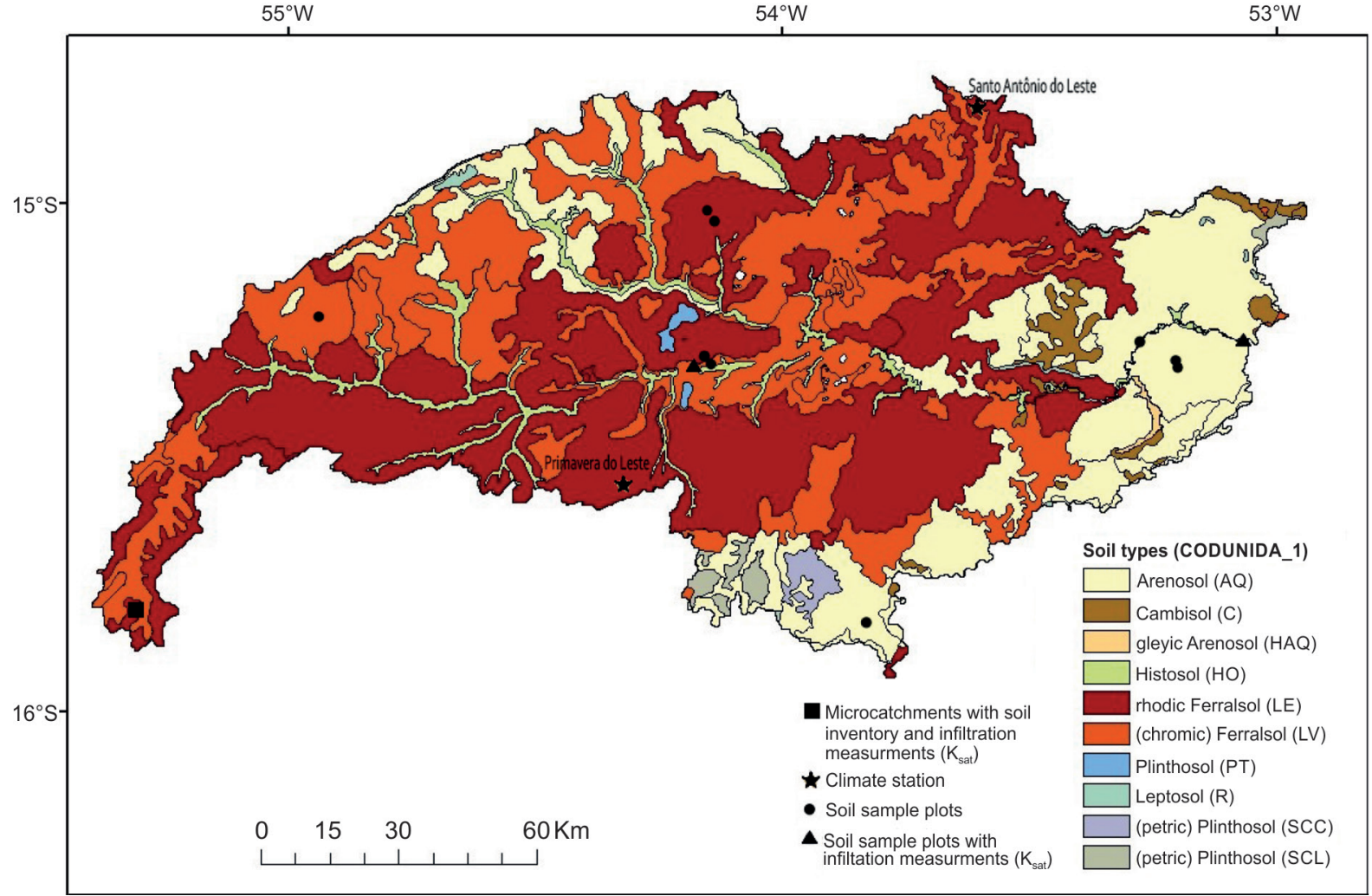

Fig. 2: Soil types in the Rio das Mortes catchment (source: Projeto RADAMBRASIL)

and low fertility (UFV no year/b; EMBRAPA 2012). The Latossolos primarily have a clayey-sandy texture with medium infiltration and good soil water storage capacity, whereas the Areias Quartzosas (sandy texture) show a very high infiltration capacity with a low soil water storage capacity. The remaining natural vegetation, concentrated along the rivers, is dominated by the Cerrado and gallery forests. Land use in this region is predominantly agricultural, and it is one of the principal production areas of maize, cotton and soybeans.

Cerrado is the tree and shrub savannah vegetation of south-west and central Brazil (Drigo 2005) and covers an area of 203 million ha (approximately $24 \%$ of the Brazilian territory; MMA 2009 and 2011; EMBrapa 2012). It is the second largest biome in South America (MMA 2009, 2011), containing approximately one third of the national biodiversity (UFV no year/a). Physiognomy and floristic composition are not homogenous, thus, Cerrado is divided into five community types along a gradient of increasing fraction of woody species (CASTRO and KAUFFMAN 1998). In the macro-watershed the Cerrado-type "Cerrado sensu strictu" predominates, a grass-herb-shrub community with open tree cover.
In 2002, $40 \%$ of Mato Grosso were covered with Cerrado vegetation (SANO et al. 2008), but from 2002 to 2008 annual deforestation activities continued until deforestation rates declined after 2008 (from 0.69 to $0.32 \% / \mathrm{a}$, MMA 2011). Hence, more than two thirds of the former Cerrado vegetation in the Rio das Mortes catchment had been cleared by 2011 . Referring to a newly created land use map, $24 \%$ of the catchment area remained Cerrado vegetation and $8.9 \%$ remained gallery forest (cf. section 3).

The climate of the study area is characterised by a strong seasonal rainfall pattern with a concentration of tropical rainfall between October and April (rainy season) and a dry season (arid months) from May to September (Fig. 3, Embrapa 2012). Mean annual precipitation range from $1200-2000 \mathrm{~mm}$ with high annual variability (long-term mean annual variation coefficient: 17\%) (ARVOR et al. 2012; EMBRAPA 2012). Because of the tropical climate with average monthly temperature differences less than $5{ }^{\circ} \mathrm{C}$ and an annual average of $22-27^{\circ} \mathrm{C}$, crops can be cultivated (throughout) the entire year. However, rain-fed agriculture is concentrated in the wet season from October until May with a main rotation of soy-corn or soy-cotton. The Rio das Mortes River can be generally classi- 

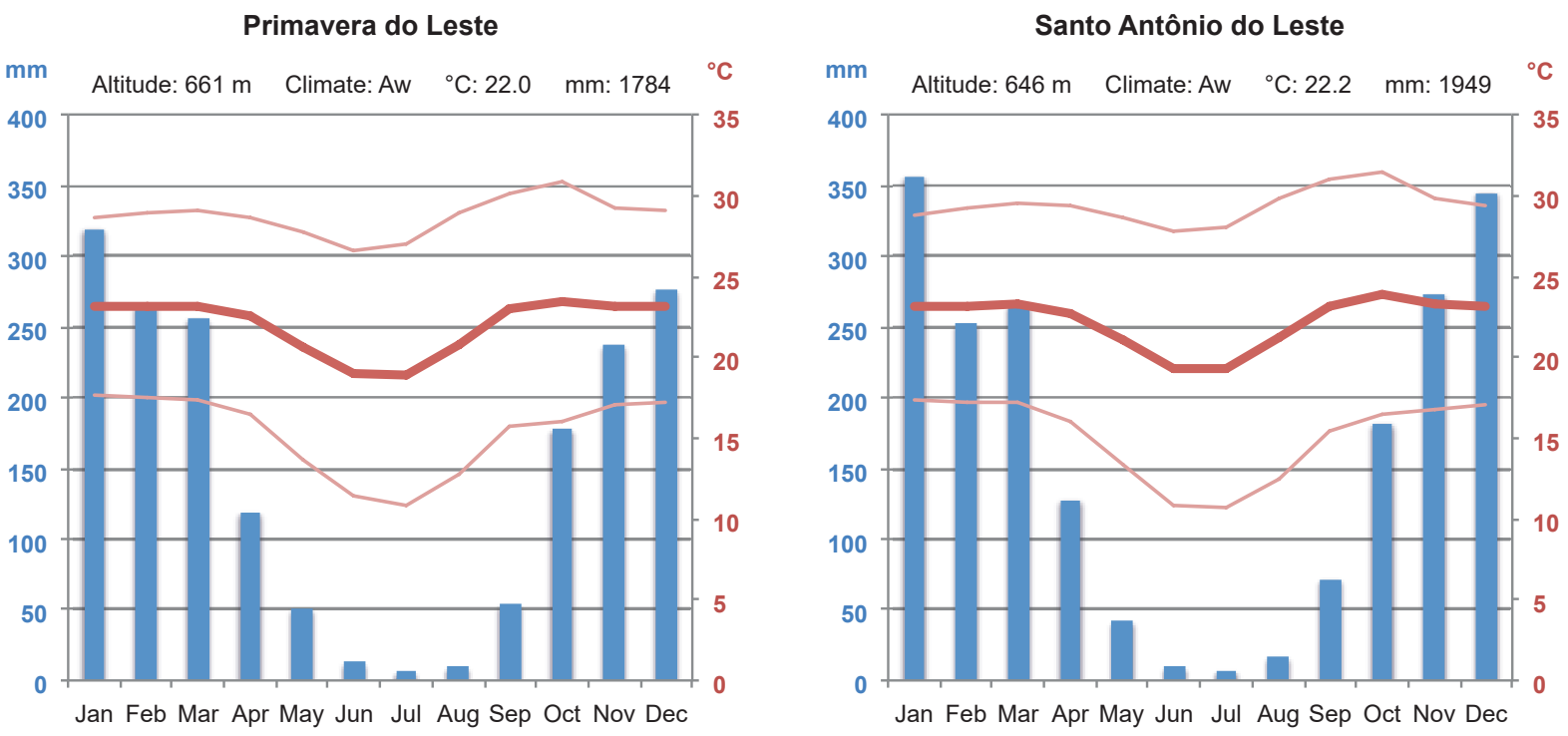

Fig. 3: Mean monthly precipitation and temperature of Primavera do Leste and Santo Antonio do Leste (source: http:// en.climate-data.org/)

fied as rain-fed and is characterized by a pronounced seasonal flow regime showing a year-to-year variability. Generally, high flows occur during the summer (rainy) season (October to April) and low flows occur during winter (dry) season (May to September). The daily flow ranges from 126 to $1615 \mathrm{~m}^{3} / \mathrm{s}$ with a longterm mean flow of $361 \mathrm{~m}^{3} / \mathrm{s}$ (Fig. 4).

\section{Application of WaSiM for water balance simulation - model set-up}

The hydrological impacts of potential land use changes on the water balance of the Rio das Mortes macro-catchment were determined using a primarily physically based modelling approach. A number of physically based distributed catchment models has been developed since the 1980s, for example IHDM, SWAT, MIKE SHE, VSAS, SAKE and WaSiM (GÜNTNER 2002). They are useful tools for the prediction of land use and climate change impacts and for the assessment of the sensitivity of the hydrological response to single parameters (BRUTSAERT 2005). Naturally, these models can only provide a simplified representation of reality due to certain aspects of the flow characteristics disregarded in the model conception. They further allow to explore the effects of different simplifying assumptions (BRUTSAERT 2005). As WaSiM includes detailed parameterisation possibilities for various soil and land use characteristics, it is suitable for the simulation of land use scenarios. Its special advantage is based on the model inherent concept of layered soils and to define the influences of different land use types and land management strategies on soil hydraulic properties (RIEGER 2012). Furthermore, WaSiM was used for simulation in the tropics of the impact of El Niño on water resource availability in Central Sulawesi, Indonesia (LeEmHuis 2005; Gerold 2012). For this reason, a single catchment approach was adopted and realised with the deterministic, spatially distributed water balance simulation model WaSiM 8.5.0 (Schulla and Jasper 2007). This approach allows a numerical simulation of the unsaturated zone including different layered soil types based on the Richards equation.

Due to its comprehensive parameterisation of soils and vegetation cover, the model is readily adjustable to the characteristics of the study catchment. Furthermore, to parameterise the different runoff processes WaSiM includes a suite of modules to calculate areal precipitation and radiation correction, evapotranspiration, interception, soil water in the unsaturated zone; further a coupled two-dimensional numerical groundwater model was used in this study (Fig. 5).

\subsection{Processing of input data}

To perform a water balance simulation, the WaSiM model requires gridded spatial data of topography, soil and land use characteristics and time series of precipitation, climate and discharge, which are detailed described in figure 5 and the following sub-sections. 


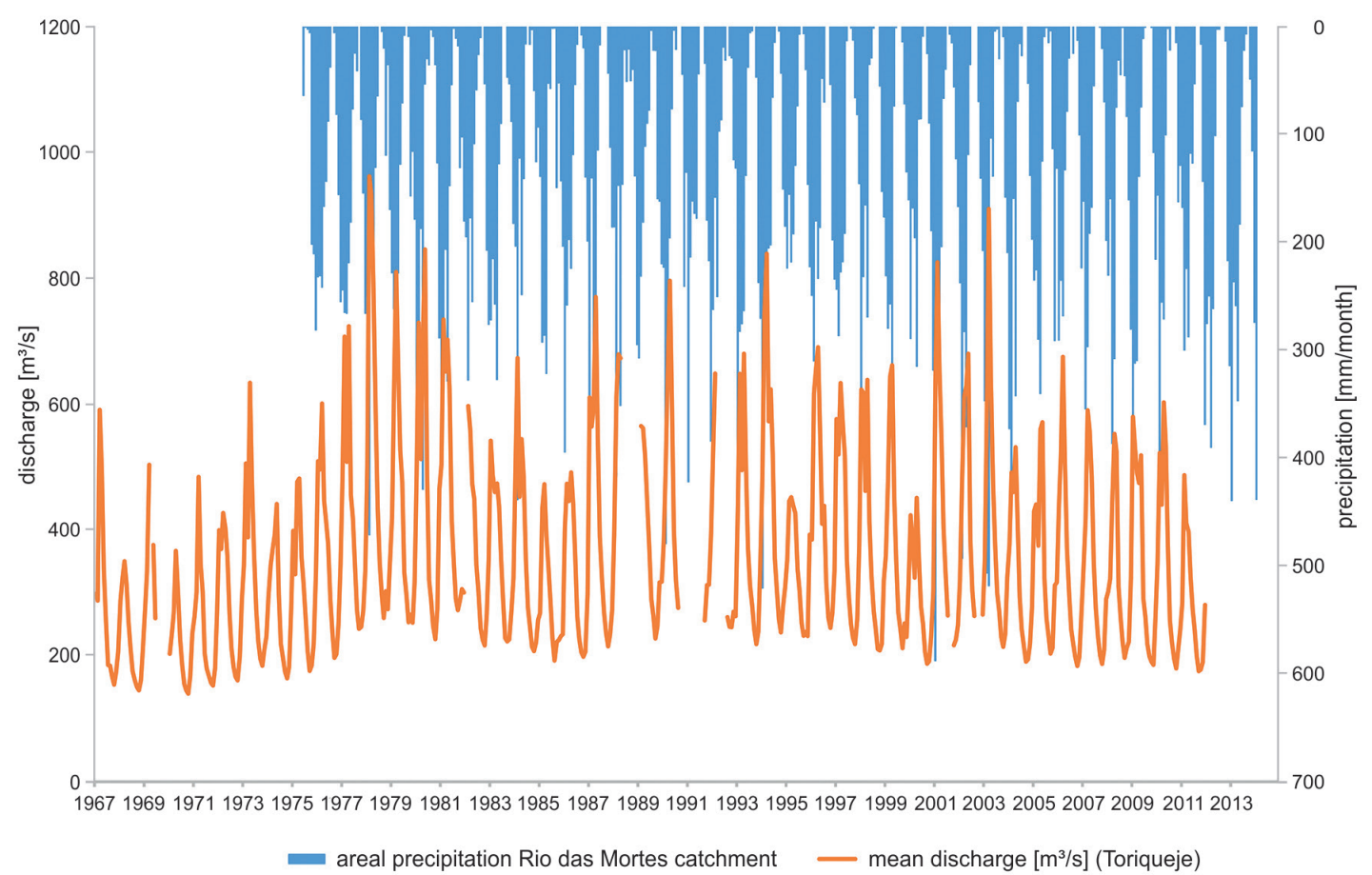

Fig. 4: Daily discharge Rio das Mortes at Toriqueje station 1967-2012 (Source: ANA 2015)

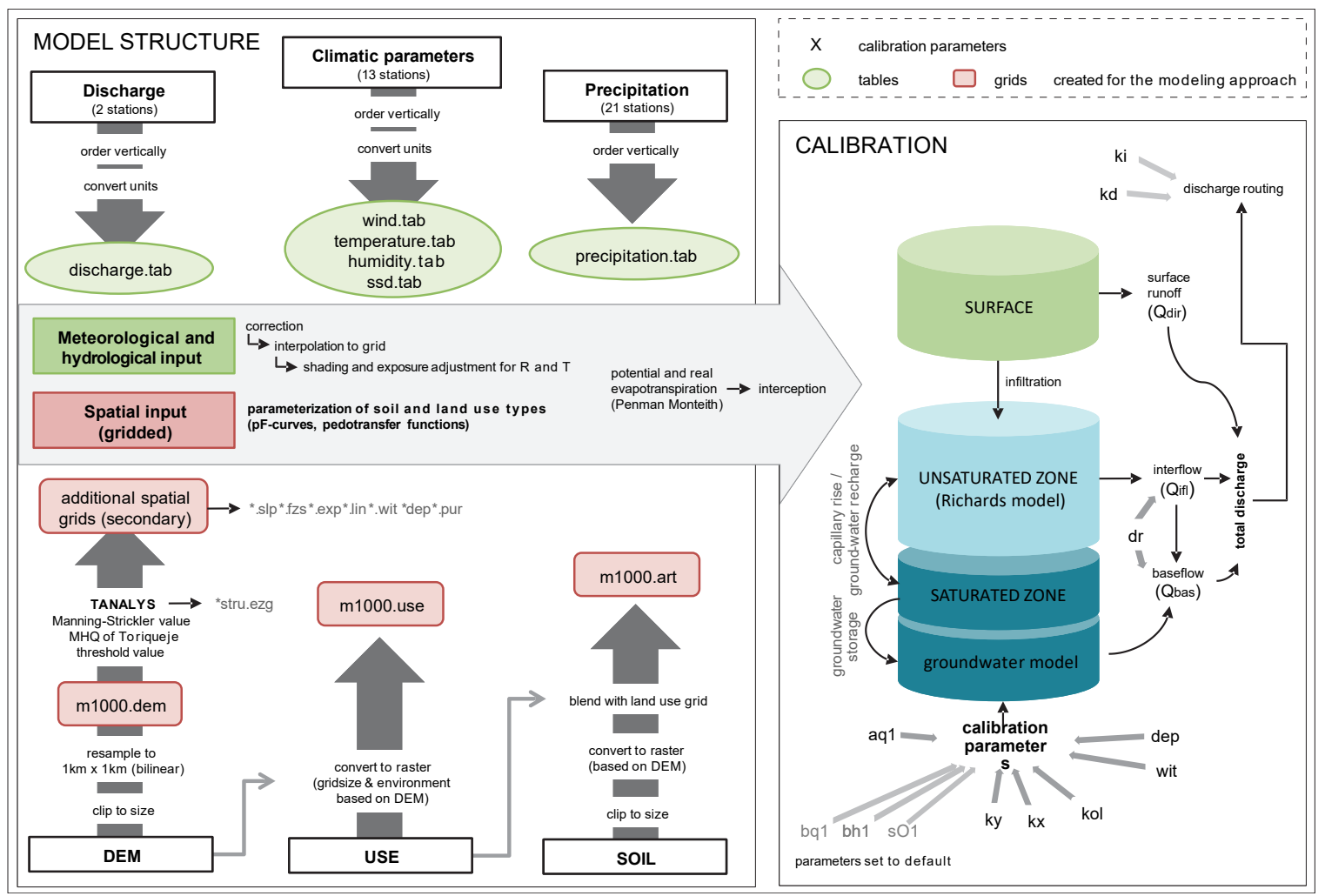

Fig. 5: Flow chart WaSiM model setup 


\subsubsection{Spatial data}

The required DEM (Digital Elevation Model) of the catchment is based on ASTER Global DEM V2Data for the whole Rio Araguaia/Tocantins region (http://gdi.carbiocial.de/). It was resampled to a cell size of $1 \mathrm{~km}^{2}$ using a bilinear resampling method and was adapted to the macro-catchment size.

The gridded soil data was derived from the soil map of the Legal Amazon 1:250 000 (Projeto RADAMBRASIL) which contains information about the spatial distribution of soil types in the study catchment and a few soil profile descriptions for the main soil types (Fig. 2).

The grid of spatial land use distribution was created as a combination of a land use classification conducted by MüLLER et al. (2014), based on LANDSAT imagery from 2009-2011, and another land use classification described in SCHLICHT (2013), based on LANDSAT imagery from 2011. Both, the soil and the land use raster were adjusted to the DEM. Before 2011 data on land use distribution only exists without differentiation of crop and pasture (categories forest/non-forest for 1988; SCHLICHT 2013), which were reclassified into categories of 2011 (Fig. 6) by statistical subdivision with community crop/pasture production data (LAMPARTER et al. 2016).

\subsubsection{Hydrological data}

Discharge data for the Rio das Mortes macrocatchment is scarce. Only two stations (from ANA), which have been recording relatively consistent data for a time period of $30-40$ years, could be used for the model set-up. The Rio das Mortes station is located in the centre of the catchment and the Toriqueje station is situated at the basin outlet (Fig. 1). Both hydrologic time series have a daily temporal resolution.

\subsubsection{Meteorological data}

Precipitation and climate data were taken from several stations within a radius of $270 \mathrm{~km}$ from the center of the study catchment. Daily precipitation time series were derived from 21 stations operated by ANA and INMET (Fig. 1, 1970-2012). Additionally, 13 climate stations of ANA and INMET were selected (Fig. 1); they provided time series of data on temperature $\left[{ }^{\circ} \mathrm{C}\right]$, relative humidity $[1 / 1]$, wind speed $[\mathrm{m} / \mathrm{s}]$ and relative duration of sunshine [1/1]. The interpolation of precipitation and climate data was per- formed by WaSiM itself with the Inverse Distance Weighting method, recommended for flat regions (Schulla 2013).

\subsubsection{Topographic analysis}

The topographic analysis of the study watershed was performed with the WaSiM tool TANALYS (Schulla 1997). In the process, further essential spatial grids were derived. Moreover, the drainage structure of the catchment and the geometry of the crosssections were calculated during the TANALYS run.

\subsubsection{Parameterisation of soils}

The soil model of WaSiM version 8.5.0 is based on a numerical, discretised solution of the Richards equation (RICHARDS 1931), which requires one discretised soil column per grid cell (RIEGER 2012). Besides the overall significance of model parameterisation (VERTESSY and ElsENBEer 1999), the character of the soil surface is particularly crucial as it decisively determines the infiltration process as well as subsequent fractioning and pathways of water (BonelL 2005).

Comprehensive measurements of soil properties, in particular water retention characteristics and soil hydraulic conductivity $\left(k_{\text {sat }}\right)$, are time consuming and cannot be done numerously on the macro scale. Consequently, the soil parameterisation was based on literature research, measurements made in three micro-catchments (soil transects, GrüNING 2014) which are part of the Rio das Mortes macrocatchment (Fig. 2) and a comparison of literature data with field measurements of saturated hydraulic conductivity $\left(k_{\text {sat }}\right)$ and $\mathrm{pF}$-curves from soil samples of this catchment ( $\mathrm{pF}$ from 1.3-4.5, Fig. 2).

Since saturated hydraulic conductivity and water retention characteristics strongly influence hydrological processes, their parameterisation is highly sensitive for hydrological modelling approaches. In this model approach, the saturated hydraulic conductivity of main soil types (rhodic Ferralsol, chromic Ferralsol, Arenosol; Fig. 2) were parameterised in accordance to own field measurements. The $k_{\text {sat }}$ of the other soil types was estimated by referring them to Carsel and Parrish (1988) and measurement values given by Hunke et al. (2014). The field measurements showed large variances of hydraulic conductivity during the wet and dry season, and also within the same seasons within the micro-catchments (Nóbrega et al. 2017; Wolf 2016). On pasture sites 
Vol. $71 \cdot$ No. 3
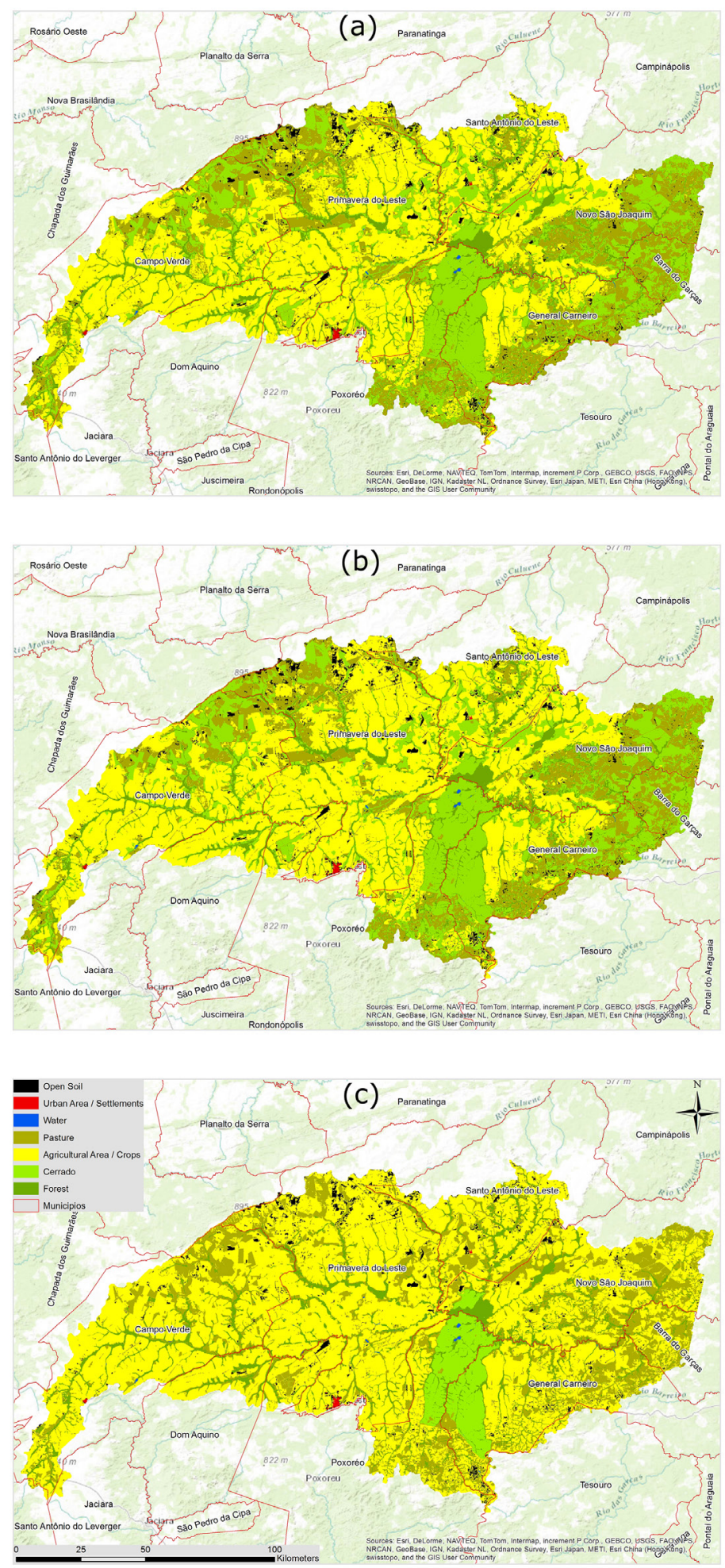

Fig. 6: Land use map 2011 and land use scenarios: a) Base line 2011, b) Scenario 1, c) Scenario 2; red border = areas of permanent protection - Cerrado area (based on satellite image analysis MüLler et al. 2014; SCHLICHT 2013; GuZHA et al. 2014 land cover scenario development) 
and partly on crop sites $k_{\text {sat }}$ values were often lower in the upper soil layers due to compaction. Native Cerrado had much higher infiltration rates than crop and pasture (Tab. 1). $k_{\text {sat }}$ in cropland is partly high, because farmers in Mato Grosso use no-tillage practices (Nóbrega et al. 2017). Due to high standard deviations maximum and minimum values were tested and chosen according to calibration results.

The use of different pedotransfer functions (PTFs) may cause up to $25 \%$ of deviation on the simulation results (RIEGER et al. 2010). In this study, PTFs in form of parameter regression functions were used to determine parameters for the retention function following the vAN GENUCHTEN model (van Genuchten 1980). The pF-curves obtained from the soil samples and laboratory measurements were used to check the suitability of existing PTFs and VAN GENUCHTEN parameter values for Brazilian soils derived from literature research.

For each soil type, the parameters of the vaN Genuchten equation (van Genuchten 1980) were calculated by using pedotransfer functions (PTFs, cf. Wösten et al. 1999; Weynants et al. 2009; Rieger 2012). The estimation of the vaN Genuchten parameters (except $n$ ) for the two Latossolos (Ferralsols) was performed using the PTF of VAN DEN BERG et al. (1997), because this equation is derived from a Latossolo database only. The van Genuchten parameter $n$ of the two Latossolos was calculated according to Tomasella et al. (2000; Level 4) due to a lack of required data for the function of VAN DEN BERG et al. (1997). The VAN GENUCHTEN parameters of the other soil types were calculated using the pedotransfer function of Tomasella et al. (2000, Level 4), which has been developed for Brazilian soils and is based on a corresponding soil database. The comparison of measured pF-curves (from field data, Wolf 2016) and the VAN GENUCHTEN parameters from the PTFs for the main soil type-land use-depth combination showed a good applicability with RMSE-values (root mean square error) of 3.2-4.8\% (Cerrado-combinations) and $3.1-8.0 \%$ (crop-combinations, $\mathrm{pF}$-curves for pasture and crop were very similar). The VAN Genuchten parameters for each PTF were then used for parameterization of the accordant parameters in the WaSiM control file (theta_sat, theta_res, alpha and par_n) for the main soil types in a depth of $0-60 \mathrm{~cm}$. With the soil types 73 soil layers were defined with a total depth of around $90 \mathrm{~m}$ and an aquifer thickness of $30 \mathrm{~m}$. Macropore infiltration is implemented in WaSiM following the "bypassflow-concept" after JANSSON and KARLBERG (2001). Potential macropore runoff is calculated for each soil layer with the depth and capacity of macropores and the reduction of the macropore capacity per meter soil depth. It is activated only when the precipitation threshold value is exceeded. During calibration, the macropore parameters were tested for sensitivity and calibrated within ranges based on literature data.

\subsubsection{Parameterisation of land use}

Because WaSiM requires a wide range of input parameters for a detailed parameterisation of each vegetation and land use type, quality and availability of input data influence modelling results. With regard to the prevailing land use types in the Rio das Mortes catchment (Fig. 6), data availability of certain required parameters is scarce, particularly for monthly values. Moreover, some contradicting parameters values can be found in the literature. Thus, the land use parameterisation was based on numerous research studies. Annual ranges and sources for the main vegetation parameter are given in table 2 . The land use types water, settlement and open soil

Tab. 1: Field measurements of $\boldsymbol{k}_{\text {sat }}$ in the Rio das Mortes catchment [cm/h]

\begin{tabular}{|c|c|c|c|c|c|c|c|c|c|c|c|c|c|}
\hline \multirow{2}{*}{\multicolumn{2}{|c|}{$\begin{array}{l}\text { Soil type } \\
\text { Depth }\end{array}$}} & \multicolumn{3}{|c|}{ Cerrado } & \multicolumn{3}{|c|}{ Pasture } & \multicolumn{3}{|c|}{ Gallery Forest } & \multicolumn{3}{|c|}{ Cropland } \\
\hline & & Min & Max & Mean & Min & Max & Mean & Min & Max & Mean & Min & Max & Mean \\
\hline \multirow{3}{*}{$\begin{array}{l}\text { घี } \\
\stackrel{\leftrightarrow}{\sim}\end{array}$} & $\mathrm{LE}$ & 10.3 & 44.4 & 28.9 & & & & & & & 0.5 & 5.0 & 2.9 \\
\hline & $\mathrm{LV}$ & 30.3 & 39.9 & 34.5 & 0.5 & 23.3 & 12.5 & 5.1 & 21.4 & 13.0 & 0.4 & 41.6 & 16.6 \\
\hline & $\mathrm{AQ}$ & 33.2 & 87.4 & 60.3 & 21.1 & 49.3 & 35.2 & 2.3 & 16.3 & 10.2 & 1.4 & 2.7 & 2.2 \\
\hline \multirow{3}{*}{$\begin{array}{l}\text { च्व } \\
\text { ठ }\end{array}$} & LE & 30.3 & 36.6 & 33.1 & & & & & & & 8.4 & 11.7 & 10.2 \\
\hline & LV & 31.6 & 40.4 & 37.3 & 7.0 & 15.5 & 10.6 & & & & 0.5 & 13.6 & 5.2 \\
\hline & $\mathrm{AQ}$ & 33.3 & 67.3 & 50.3 & 29.8 & 47.6 & 38.9 & 9.0 & 21.7 & 16.0 & 3.2 & 10.6 & 6.0 \\
\hline
\end{tabular}

Values (3 repetitions) from soil sample plots (Wolf 2016) and transects in the micro-catchments (NóBregA et al. 2017); (Fig. 2) with: cerrado $\mathrm{n}=16$, pasture $\mathrm{n}=14$, gallery forest $\mathrm{n}=9$, cropland $\mathrm{n}=16 . \mathrm{LE}=$ rhodic Ferralsol, $\mathrm{LV}=$ haplic Ferralsol, $\mathrm{AQ}=$ Arenosol 
Tab. 2: Main vegetation parameters (range of monthly values, sources)

\begin{tabular}{|c|c|c|c|c|}
\hline Parameter & Cerrado & Gallery Forest & Cropland & Pasture \\
\hline Albedo & $0.25-0.3$ & $0.1-0.2$ & $0.17-0.2$ & 0.2 \\
\hline $\begin{array}{c}\text { VCF (vegetation } \\
\text { covered fraction } \\
\qquad\left[\mathrm{m}^{2} / \mathrm{m}^{2}\right]\end{array}$ & $0.5-0.8$ & $0.7-0.95$ & $0.2-0.5$ & 1.0 \\
\hline LAI $\left[\mathrm{m}^{2} / \mathrm{m}^{2}\right]$ & $2-5$ & $5-8$ & $0.5-4$ & $2-4$ \\
\hline Root depth $z$ [m] & $3-5$ & 3.7 & $0.3-1.6$ & $0.7-1.2$ \\
\hline $\begin{array}{c}\text { Stomata resistance } r_{c} \\
{[\mathrm{~s} / \mathrm{m}]}\end{array}$ & $70-80$ & $80-90$ & $50-100$ & $50-70$ \\
\hline $\begin{array}{l}\text { Roughness length } \\
\text { factor } z_{\mathrm{o}}[\mathrm{m}]\end{array}$ & $0.3-0.34$ & $2.7-3.0$ & $0.01-0.1$ & $0.01-0.04$ \\
\hline $\begin{array}{c}\text { Interception capacity } \\
{[\mathrm{mm} / \mathrm{LAI}]}\end{array}$ & 0.2 & 0.2 & 0.2 & 0.1 \\
\hline
\end{tabular}

Sources: Allen et al. 1998; Breuer et al. 2003; Canadell et al. 1996; Castro and Kauffmann 1998; ECKhardt 2003; Ferreira 2004;

Giambelluca 1996; Güntner 2002; Hölscher et al. 2005; Kleinhans 2004; Körner 1994; Niehoff 2001; Schlicht 2013; UFV no year/a

were parameterised roughly according to SCHULLA (2013). Main parameters were tested for model sensitivity and adjusted step by step within reasonable ranges during calibration. Calculated evapotranspiration (ETp with Penman-Monteith, ETa according to available soil moisture) by WaSiM was compared with results from Brazilian studies in the Cerrado biome (Andrade et al. 2014; Lathuillière et al. 2012; Oliveira et al. 2014; Strauch and VolK 2013). Interception loss is calculated in $\mathrm{WaSiM}$ with the parameters LAI, vegetation covered fraction (VCF) and interception capacity.

Moreover, parameterisation was performed in accordance with the following assumptions:

- Cerrado was parameterised as one main vegetation type (Cerrado sensu strictu),

- For the gallery forest parameters of tropical semideciduous forest were adopted, when no detailed values of gallery forests could be found,

- Cropland was parameterised as one land use type with different monthly values depending on the current crop. According to seeding and harvesting periods, soybean values were parameterised from October to February, values for corn were inserted adjacently from March to June and from July to September cropland was parameterised as fallow.

\subsection{Model calibration}

The accuracy and differences of particular calibration steps were evaluated according to three performance criteria. The first criterion is the Nash-Sutcliffe efficiency (NASH and Sutcliffe $1970)$ with values $>0.7$ indicating a fair calibration and values $>0.85$ indicating a good agreement (ANDERSEN et al. 2001). The second criterion was the proportion of simulated and measured discharge to check the fit of flow volume; and third the graphical performance, checked by a comparison of the runoff hydrographs and the simulated runoff components.

Model calibration was performed for the Toriqueje gauging station (750 calibration runs). For model calibration, a three-year period of measured data was chosen: 01.11.1985-31.10.1988 (cf. section 4, Fig. 9). This period includes the normal annual variability of rainfall with $1,300-1,800 \mathrm{~mm}$ (60\% of years from 1961-2012). Initialisation runs were run over two years $(1.11 .1983-31.10 .1985)$ to establish a balanced groundwater table and reasonable base flow. Those periods were chosen based on the data availability and quality of meteorological and hydrological data (Fig. 3 and Fig. 4). In contrast to the majority of data, these time periods exhibit nearly continuously measured discharge and climate data without large gaps. Also Mann-Kendal test of annual rainfall and discharge (1970-2010) by GUZHA et al. (2013) showed that the chosen calibration and validation period represent the long term normal range (residuals near zero). First calibration runs were tested with spatial grid resolution of 100 $\mathrm{m}^{2}, 1 \mathrm{~km}^{2}$ and $4 \mathrm{~km}^{2}$. Finally as a compromise between calibration performance and computer simulation time the grid resolution of $1 \mathrm{~km}^{2}$ was chosen. 
According to Rieger (2012:141) the calibration was done following consecutive steps:

- Establishing a balanced groundwater table throughout the year (value of GW-Initialisation $g w \_$init and number of initialisation runs)

- Parameterising a reasonable base flow (aq , wit \& dep, kx, \& ky , kol)

- Parameterising of interflow

- Shortening or stretching of flow peaks

For the first calibration runs the groundwater model was deactivated. Numerous efforts to generate a sufficient amount of base flow with the calibration of the conceptual scaling factor $Q_{0}$ and retention constant $k_{b}$ failed. Therefore, the sensitivity of the soil parameterisation was tested based on the increases of $k_{\text {sat }}$ and layer thickness. But the amount of base flow in the Rio das Mortes catchment was rather high, therefore the groundwater model was activated to fit the prevailing runoff processes and to achieve realistic modelling results. The groundwater model contains several additional conceptual parameters, which were calibrated with the second calibration runs without changing the physically based soil and land use parameters. The parameters presented in figure 5 and table 3 were selected for calibration.
GuzHA et al. (2014) and the calibration runs showed that in this catchment with a base flow index of 0.67 the groundwater parameters and the flow components $k_{d} / k_{i}$ had a great influence on the simulated hydrographs (section 4, Fig. 8).

The parameters were manually adjusted and assessed through calibration runs. Following each sensitivity analysis for one specific parameter, a new baseline scenario was created that best resembled measured data with current parameter settings. Then the next parameter was tested. Model sensitivity was analyzed graphically with the WaSiM helptool Graphlines by comparing changes in the output files for groundwater table (gwst.stat), baseflow (qbas.stat), interflow (qifl.stat), direct discharge (qdir.stat) and routed discharge (qgko.stat). Influences of the parameter settings were assessed with special focus on behavior in the rainy season and the dry season and summarized in section 4 , figure 8 .

\subsection{Model validation}

With the final calibration parameter set modelling results were validated for a different time period with consistent discharge and climate data (01.11.1997-31.10.2000) and land use map from 2011.

Tab. 3: WaSiM parameters selected for the second calibration runs

\begin{tabular}{|c|c|c|c|c|}
\hline \multirow[t]{2}{*}{ Parameter } & \multirow[t]{2}{*}{ Unit } & \multicolumn{2}{|c|}{ Range } & \multirow[t]{2}{*}{ Description } \\
\hline & & Min & Max & \\
\hline \multicolumn{5}{|c|}{ Calibration parameters for the base flow } \\
\hline gw_level & {$[-]$} & 1.8 & 5 & initialization parameter of groundwater level \\
\hline aq1 & {$[\mathrm{m}]$} & 5 & 100 & aquifer thickness \\
\hline $\mathrm{k}_{\mathrm{x}}$ & & $1 \mathrm{e}^{-7}$ & $1 \mathrm{e}^{-4}$ & saturated hydraulic conductivity of groundwater in \\
\hline $\mathrm{k}_{\mathrm{y}}$ & & $1 \mathrm{e}^{-7}$ & $1 \mathrm{e}^{-7}$ & $\mathrm{x}$-y-direction \\
\hline kol & & $1 \mathrm{e}^{-7}$ & $5 e^{-5}$ & leakage factor for interchange between ground- and surface water $(<\mathrm{kx}, \mathrm{ky})$ \\
\hline wit & {$[\mathrm{m}]$} & 3 & 10 & width of the flow channel \\
\hline dep & [m] & 3 & 9 & depth of the flow channel \\
\hline \multicolumn{5}{|c|}{ Flow components accounting for the routed discharge } \\
\hline$d_{r}$ & {$\left[\mathrm{~m}^{-1}\right]$} & 3 & 50 & drainage density for interflow \\
\hline $\mathrm{k}_{\mathrm{rec}}$ & {$[-]$} & 0.1 & 0.9 & $k_{\text {sat }}-$ recession \\
\hline $\mathrm{k}_{\mathrm{d}}$ & [h] & 10 & 750 & storage coefficient for surface runoff \\
\hline $\mathrm{k}_{\mathrm{i}}$ & [h] & 10 & 750 & storage coefficient for interflow; recommended is $k_{d}=k_{i}$ (SCHULLA 2013) \\
\hline
\end{tabular}




\subsection{Land use scenarios}

Based on general trends in land use as they recently occur in the macro-catchment (MACEDO et al. 2012) and realistic regional simulation results of land use change until 2030 (SCHALDACH et al. 2017, this issue), two land use scenarios were simulated to analyse the impact of a respective land cover change.

In the first scenario small pasture sites $\left(<1 \mathrm{~km}^{2}\right)$ surrounded by cropland area were converted into cropland (GUZHA et al. 2014), or they became uncultivated areas of Cerrado vegetation if surrounded by Cerrado patches (GuzHA et al. 2014; Fig. 6b). The second land use scenario contains more drastic land cover changes. All pastures were converted into cropland and afterwards all Cerrado patches were transformed into pasture sites (GuZHA et al. 2014; Tab. 4; Fig. 6c).

With the changed combination of soils and land uses, the soil and vegetation parameterisation was adjusted for the scenarios (land use dependent parameters). The scenario simulation runs were run over the same three-year period as the calibration run (01.11.1985- 1.10.1988, base line).

\section{Results}

\subsection{Annual rainfall and streamflow}

The highest deforestation rate in Mato Grosso was found after 1977 with the first pioneer settlers, followed by the agro-industrial expansion phase from 1988 on (CoY and Klingler 2014). In the Rio das Mortes catchment, the annual deforestation rate decreased by nearly half after 1998
$(1998-2007=2.8 \%)$ compared to $1988-1998(4.6 \%)$ (Schlicht 2013). GuZha et al. (2013) tested annual variability of rainfall and discharge over a long time series (1967-2007) of daily data to determine any long term trend by using Mann-Kendall non-parametric test. While they found no trend in the rainfall series, the decadal flow duration curves (Fig. 7) showed a pronounced increase in discharge after the 1968-1977 decade. These results indicate that stream flow trends are influenced by other forces as deforestation with subsequent pedo-hydrological changes with upper soil compaction (increase of bulk density, decrease of infiltration) as shown in other studies (Hunke et al. 2014; Wolf 2016).

The highest deforestation rate in Mato Grosso was found after 1977 with the first pioneer settlers, followed by the agro-industrial expansion phase from 1988 on (CoY and KLINGLer 2014). In the Rio das Mortes catchment, the annual deforestation rate decreased by nearly half after 1998 (1998-2007 = $2.8 \%$ ) in compared to 1988-1998 (4.6\%) (SCHLICHT 2013).

\subsection{Calibration results}

During calibration the sensitivity of the groundwater parameters (e.g. aquifer thickness, depth and width of the stream, leakage factor, groundwater conductivity) and conceptual soil parameters (drainage density, recession constants of interflow and direct discharge), also some physically based soil parameters like $k_{\text {sat }}$ number and thickness of single soil layers, and macropore values were tested. Results for the highly sensitive parameters are summarized in table 5 and figure 8.

Tab. 4: Areal proportion of land use types in 2011 and Scenario 1 and 2 [\%]

\begin{tabular}{ccccc}
\hline Land use type & $\begin{array}{c}2011 \\
\text { (base line) }\end{array}$ & $\begin{array}{c}\text { Scenario 1 } \\
\text { (without } \\
\text { protected area) }\end{array}$ & $\begin{array}{c}\text { Scenario 2 } \\
\text { (without } \\
\text { protected area) }\end{array}$ & $\begin{array}{c}\text { Protected Area } \\
\left(1024.59 \mathrm{~km}^{2}\right)\end{array}$ \\
\hline Gallery Forest & 8.9 & 8.3 & 8.7 & 0.0 \\
Cerrado & 19.1 & 20.9 & 70.4 & 0.2 \\
Cropland & 48.8 & 50.9 & 19.1 & 0.9 \\
Pasture & 22.0 & 18.8 & 0.2 & 0.6 \\
Water & 0.2 & 0.2 & 0.2 & 0.0 \\
Settlement & 0.2 & 0.2 & 0.6 & 0.0 \\
Open Soil & 0.8 & 0.7 & 0.0 \\
\hline
\end{tabular}

Source: based on satellite image analysis MüLLER et al. 2014; SCHLICHT 2013 and land cover scenario development GuZHA et al. 2014 


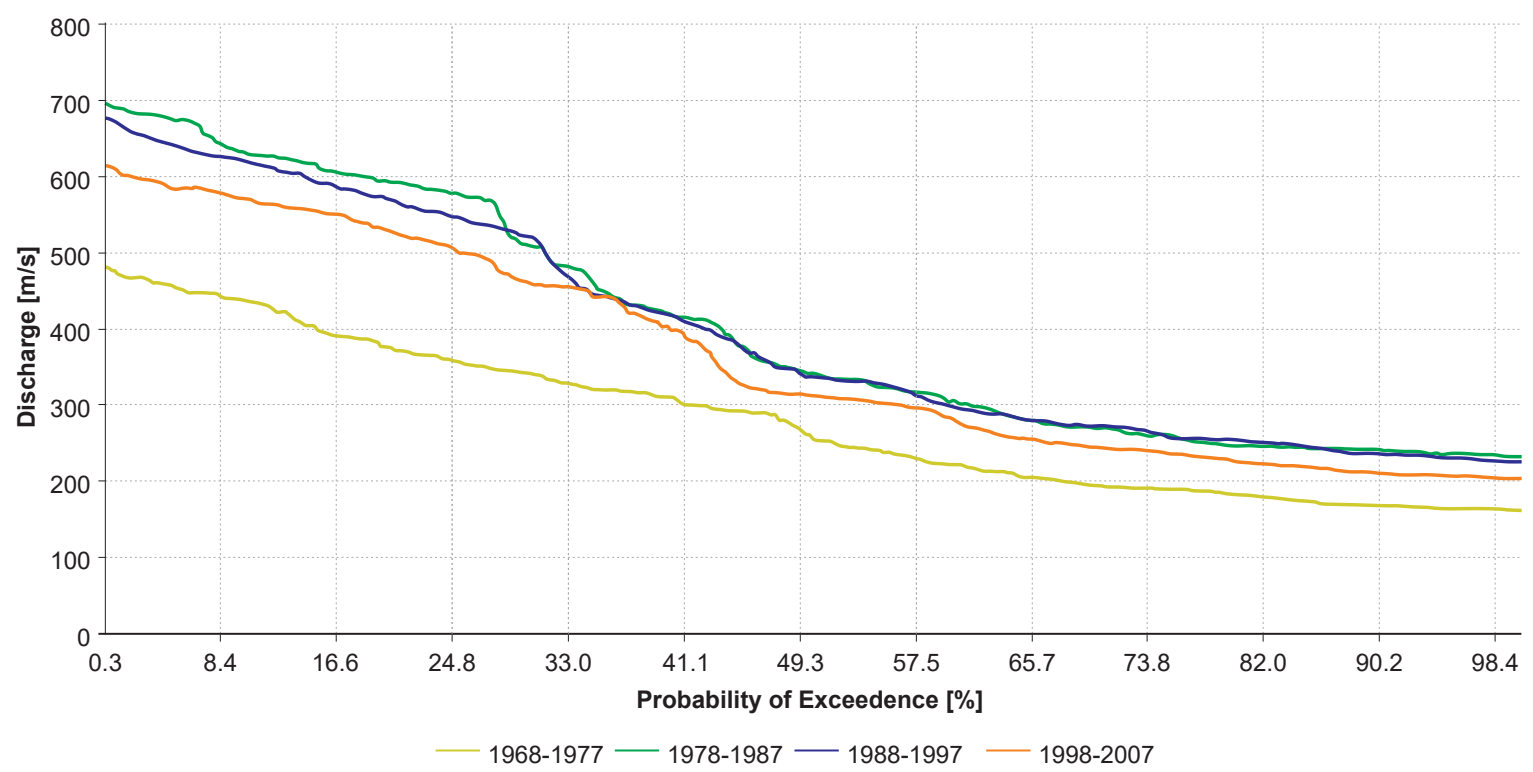

Fig. 7: Decadal flow duration curves for stream flow measured at the ANA station 26050000 (Toriqueje) 1968-2007 (GUZHA et al. 2013)

\subsubsection{Soil parameter}

A ten times increased conductivity of the soil did not result in a change of the groundwater table nor the base flow, but resulted in more balanced flow dynamics. The interflow increases and the direct discharge decreases due to an increased $\mathrm{k}_{\mathrm{sat}}$. The reduction of the number of soil layers to maximal four layers in the first 1-2 $\mathrm{m}$ of each soil influences the dynamic and volume of the routed discharge. This change causes the peaks of the interflow to decrease slightly whereas the routed discharge and flow volume are increasing. The reduction of the total number of soil layers for all soil types from 40 to 30 layers does not have an effect on discharge components. The total thickness of soil layers was set to $30 \mathrm{~m}$. A decrease of all van GenuChTEN (1980) parameter values of the used pedotransfer function of $20 \%$ lowers the groundwater level and the base flow. In response to decreased VAN GENUCHTEN parameter values the peaks of the interflow diminish whereas the peaks of the routed discharge increase. The calculated discharge volume does not change significantly. The model is as well not sensitive to the macropore parameters. A radical reduction of the macropore threshold down to zero and a distinct increase of macropore capacity change the dynamics and the peaks of the specific discharge components only minimally.

Tab. 5: Sensitivity of calibration parameters and soil parameters

\begin{tabular}{|c|c|c|c|c|c|c|}
\hline Parameter & volume & GW-level & base flow & interflow & routed discharge & peaks \\
\hline $\mathrm{aq}_{1}$ & + & + & + & o & + & + \\
\hline kol & ○ & ○ & ० & ○ & ○ & $\circ$ \\
\hline$k_{x} \& k_{y}$ & + & $\circ$ & + & ○ & ० & + \\
\hline dep & + & + & + & o & + & + \\
\hline wit & $\circ$ & ○ & $\circ$ & ○ & $\circ$ & $\circ$ \\
\hline $\mathrm{dr}$ & ○ & ० & o & o & o & $\circ$ \\
\hline $\mathrm{k}_{\mathrm{i}} \& \mathrm{k}_{\mathrm{d}}$ & - & - & - & ○ & o & ○ \\
\hline $\mathbf{k}_{\text {rec }}$ & - & - & - & - & - & - \\
\hline$k_{\text {sat }}$ & + & ○ & ० & ० & ○ & $\circ$ \\
\hline macropore values & ○ & - & - & - & - & ○ \\
\hline number of layers & ○ & ० & o & ○ & ○ & ○ \\
\hline
\end{tabular}

$+=$ highly sensitive, $\mathrm{o}=$ medium sensitive (only strong reaction at great changes), - = not sensitive 


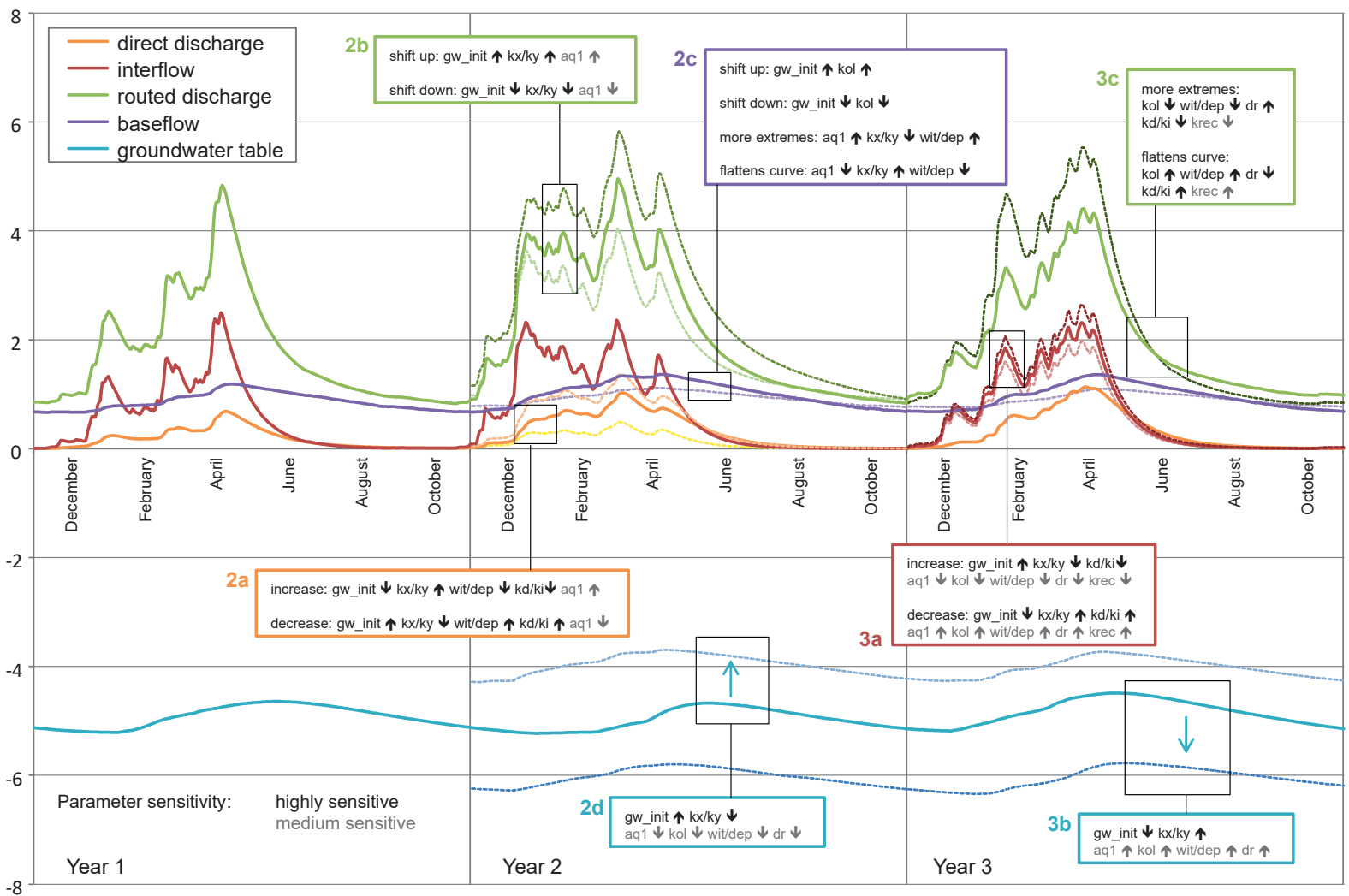

Fig. 8: Sensitivity of typical discharge components parameters (after MEISTER 2014 and WoLf 2016)

\subsubsection{Groundwater and conceptual soil parameter}

An increase of the parameters of the flow channel geometry, i.e wit and dep, leads to a lowered groundwater level whereas the base flow is increased (Fig. 8: 2a, 3b). Further, these parameters cause peaks of the routed discharge to lower slightly and cause a higher discharge in the dry season. Thus, they also lead to an increased calculated discharge volume and an improved NScoefficient. Modelling results react more sensitively to stream depth (see Tab. 5). The model is not sensitive to the aquifer thickness parameter $a q_{1}$ when changing it from 10 to $30 \mathrm{~m}$, but it becomes sensitive to the value of $100 \mathrm{~m}$ (lowers groundwater level, Fig. 8: 3b). Furthermore, the peaks of the interflow and of the routed discharge decrease in response to the increased aquifer thickness (Fig. 8: 3a). Consequently, the aquifer thickness also influences the discharge volume. Especially the parameters for groundwater conductivity and leakage, $k_{x}, k_{y}$ and $k_{0}$, are highly relevant for the modelled discharge dynamics and volume. The leakage factor kol influences the height of the groundwater level inversely (Fig. 8: 2d, 3b). When kol is decreased the groundwater rises, but the base flow is lowered (Fig. 8: 2d). Additionally, the decrease of kol slightly increases the peaks of the interflow and the routed discharge. Further, the low flow periods of the routed discharge decrease (Fig. 8: 3a, 3c).

But the impact of $k_{x}$ and $k_{y}$ on distinct discharge components is stronger than those of kol. An increase of $k_{x}$ and $k_{y}$ lowers the groundwater table and rises the base flow (Fig. 8: 3b, 2a). Thus, they also influence the height of the routed discharge during low flow periods.

Most of the calibrated parameters of the groundwater model show a high sensitivity (see Tab. 5).

If $d_{r}$ is decreased, the groundwater level rises and the peaks of the routed discharge decline, but only to a small extent (Fig. 8: 2d). The model is moderately sensitive to this parameter. The retention constants for overland flow and interflow, $k_{d}$ and $k_{i}$, mainly influence the shape of the discharge hydrograph, in terms of shortening or stretching it, without changing the generated flow volume (Fig. 8: 3d). 
4.3 Model performance for selected parameter sets

The parameters found to influence the modelled discharge were executed each over a wide range in overall more than 750 calibration runs. The WaSiM model showed some weaknesses to simulate the high fraction of base flow dominating the runoff characteristics of the Rio das Mortes catchment and to model the annual seasonality of precipitation and discharge ('dry and wet season'). Therefore, without available control parameters as groundwater level measurements in the catchment the groundwater parameters were crucial to simulate groundwater level and baseflow. Recession constants interflow and overflow $\left(k_{i}\right.$ and $k_{d}$ ) were sensitive to the reaction of rain events (interflow, peaks). Not expected was the high influence of the flow channel geometry, due to the wide flat basin. Most of the calibrated parameters of the groundwater model show a high sensitivity (Tab. 5). Finally, the main calibration parameters to raise the ground water level to 5-10 meters were: number of soil layers doubled to produce more interflow, values of $k_{\text {sat }}$ raised to the average values measured in the dry season (max. in Tab. 1). Together with the parameter macocapacity $(\mathrm{mm} / \mathrm{h})$ for soils under crop and pasture with 3.5, for gallery forest 10 and 5 for Cerrado and maximum depth of macropores adjusted to the root- ing depth model performed well for routed discharge also in the dry season and a reasonable groundwater table around $-6 \mathrm{~m}$.

\subsubsection{Evapotranspiration}

The evapotranspiration calculated by WaSiM (ETa) was compared with other studies for the four dominating land uses. Visual analysis showed the following results: increasing interception capacity by a factor 2 led to a slight parallel downward shift of all discharge components. Increasing the rooting depth by a factor 1.5 showed no reaction of the discharge components at all. Similar results were achieved for reducing the soil surface resistance factor by half and setting the VCF value to $100 \%$ for all land uses (before: $80 \%-95 \%$ ). Doubling the roughness length factor $z_{0}$ led to a parallel downward shift of all discharge components, with a much stronger effect than increasing interception capacity. To conclude, model discharge components proved to be moderately sensitive to changes in the interception capacity value and strongly sensitive to the roughness length factor. ETa could be raised only slightly from September to April and with an over modulation of values for roughness length and interception capacity $\left(+0.5 \mathrm{~mm} \mathrm{~d}^{-1}\right.$, Wolf 2016). Table 6 shows

Tab. 6: Evapotranspiration (ETa) of dominant land use types from literature sources and calculated by WaSiM for calibration runs $[\mathrm{mm} / \mathrm{d}$ and $\mathrm{mm} / \mathrm{yr}]$

\begin{tabular}{|c|c|c|c|c|c|}
\hline Land use & Wet season & Dry season & Year ETa & Year $\mathbf{P}$ & Year ETo \\
\hline Gallery Forest & $3.7 \pm 23$ & $3.1 \pm 31$ & $\begin{array}{c}1104 \pm 28^{*} \\
1361^{1}\end{array}$ & $1692 *$ & $1134 *$ \\
\hline Cerrado & $3.1 \pm 26$ & $2.3 \pm 24$ & $\begin{array}{c}1004 \pm 24^{*} \\
820-994^{1} ; 831^{2}\end{array}$ & $1696^{*}$ & $\begin{array}{l}1134^{*} \\
1218^{2}\end{array}$ \\
\hline Pasture & $2.2 \pm 27$ & $1.2 \pm 44$ & $\begin{array}{c}639 \pm 31^{*} \\
721^{1}\end{array}$ & $1779 *$ & $1134 *$ \\
\hline Cropland & $3.2 \pm 32$ & $0.9 \pm 28$ & $\begin{array}{c}760 \pm 33^{*} \\
731^{1}\end{array}$ & $1669 *$ & $1134 *$ \\
\hline \multicolumn{6}{|c|}{ Weighted average based on land use distribution 2011 (Tab. 4) } \\
\hline Catchment & 3.0 & 1.2 & 816 & $1750 * *$ & \\
\hline $\begin{array}{l}\text { Calibration run } \\
87 / 88\end{array}$ & 3.1 & 1.3 & 845 & 1742 & 1194 \\
\hline $\begin{array}{l}\text { Calibration run } \\
86 / 87\end{array}$ & 2.8 & 1.2 & 821 & 1338 & 1183 \\
\hline$\Delta$ & $-0.2-0.1$ & $0-0.1$ & $5-29$ & & \\
\hline
\end{tabular}

Mean values with relative sd (\%) from spatially averaged daily values

*after microcatchment studies (NÓBREGA et al. 2015); **long term average after GuZHA et al. 2013;

${ }^{1}$ Oliveira et al. 2014; ${ }^{2}$ Lima et al. 2001 
the calculated ETp and ETa by WaSiM compared with literature values and own results from the micro-catchments (NóBregA et al. 2015). The deviation of expected ETa estimated from literature values and calculated real ETa is relatively small (Tab. 6), therefore parameterization of land use (vegetation parameter Tab. 2) seems realistic.

\subsubsection{Final calibration}

With the results of the sensitivity analysis a final calibration run with a NASH-Sutcliffe (1970) coefficient of 0.81 was achieved (Tab. 7). The simulated discharge volume is of the same magnitude as the measured discharge volume at the Toriqueje gauge (Fig. 9; Tab. 7). Moreover, with this model set-up, the dry season flow of the simulated discharge is exclusively constituted by the simulated base flow. This is in accordance with the natural discharge dynamics of this region (GuZHA et al. 2013).

\subsection{Model validation}

A Nash-Sutcliffe (1970) coefficient of 0.68 demonstrated the quality of the model calibration (Tab. 7). Mainly the begin of the rainy season was underestimated. The discharge dynamics show slightly more divergence to the measured discharge than during the calibration period. Although the base flow mainly contributes to the dry season flow like in the calibration run, the peak discharges in the rainy season are over-estimated due to a combination of over-estimated peaks of base flow and interflow (Fig. 10).

\subsection{Scenario simulation results}

The calibration run (1985-1988) is taken as the base line scenario. The two simulated scenarios (see 3.4) are in accordance with the land use change scenarios, developed in the carbiocial pro-

Tab. 7: Performance criteria for calibration and validation

\begin{tabular}{|c|c|c|c|c|c|c|c|}
\hline & \multicolumn{2}{|c|}{$\begin{array}{c}\text { Mean measured } \\
\text { discharge }\end{array}$} & \multicolumn{2}{|c|}{$\begin{array}{c}\text { Mean simulated } \\
\text { discharge }\end{array}$} & \multirow[t]{2}{*}{$\begin{array}{l}\text { Nash- } \\
\text { Sutcliffe }\end{array}$} & \multirow[t]{2}{*}{$\begin{array}{l}\text { Vsim/ } \\
\text { Vmeas }\end{array}$} & \multirow[t]{2}{*}{$\begin{array}{r}\text { Base flow/ } \\
\text { Total runoff }\end{array}$} \\
\hline & {$[\mathrm{mm} / \mathrm{d}]$} & {$\left[\mathrm{m}^{3} / \mathrm{s}\right]$} & {$[\mathrm{mm} / \mathrm{d}]$} & {$\left[\mathrm{m}^{3} / \mathrm{s}\right]$} & & & \\
\hline Calibration & 1.79 & 347.04 & 1.69 & 327.65 & 0.81 & 0.95 & 0.67 \\
\hline Validation & 1.98 & 383.88 & 1.96 & 380.00 & 0.68 & 0.99 & 0.68 \\
\hline
\end{tabular}

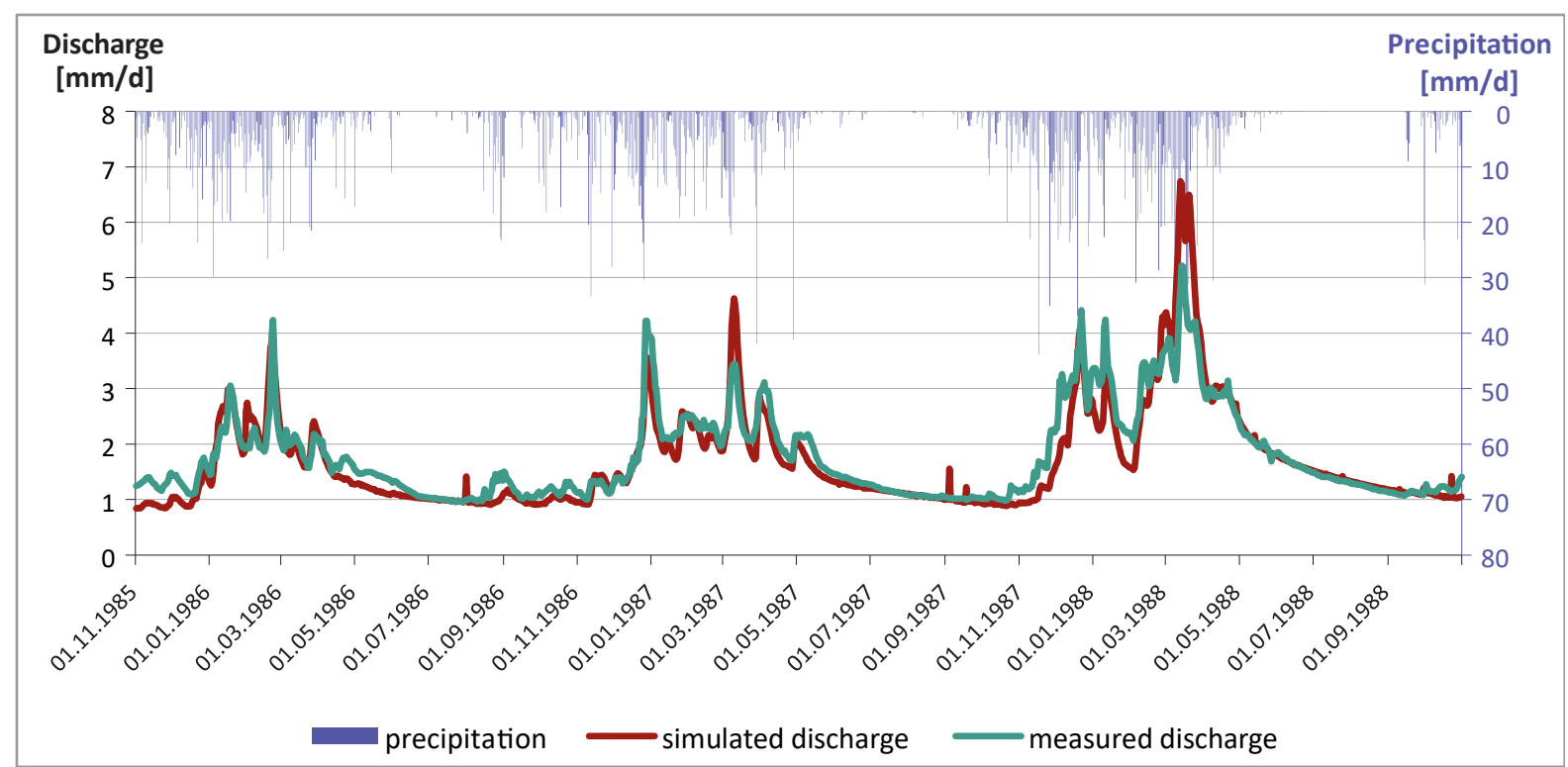

Fig. 9: Precipitation, measured and simulated discharge at Toriqueje gauging station for the calibration period 


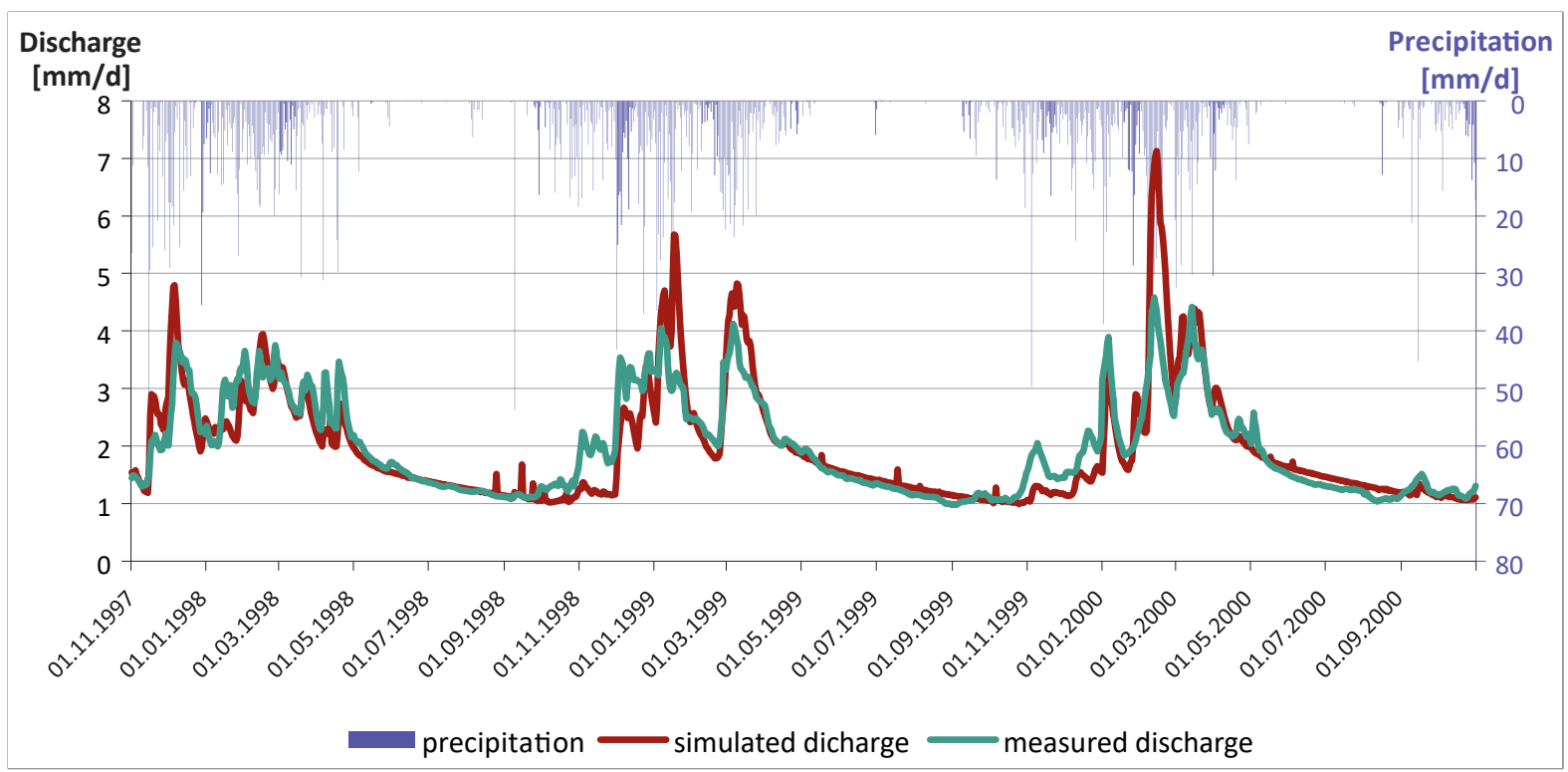

Fig. 10: Measured and simulated routed discharge at the Toriqueje gauging station for the model validation period

ject (www.carbiocial.de) with Legal Intensification (Scenario 1) and Trend (Scenario 2) (Schaldach et al. 2017, this issue).

The results of the base line scenario show that between dry and wet year the total runoff clearly increases with precipitation. The amount of base flow is always high in the watershed $(67 \%$ of total runoff), whereas the amount of surface runoff is small $(8 \%$ of total runoff). The base flow is the only main contributor to the total runoff in the dry season (Fig. 11 and Tab. 8). In the rainy season, the discharge peaks result from an increase of all discharge components. Whereas portion of base flow on total discharge decrease from the dry to the wet year, interflow and surface flow increase on peak discharges more than base flow (compared 1986/87 to $1987 / 88$ ).

The simulation of all three land use scenarios generally result in similar magnitudes of water yield, runoff dynamics and percentages of the discharge

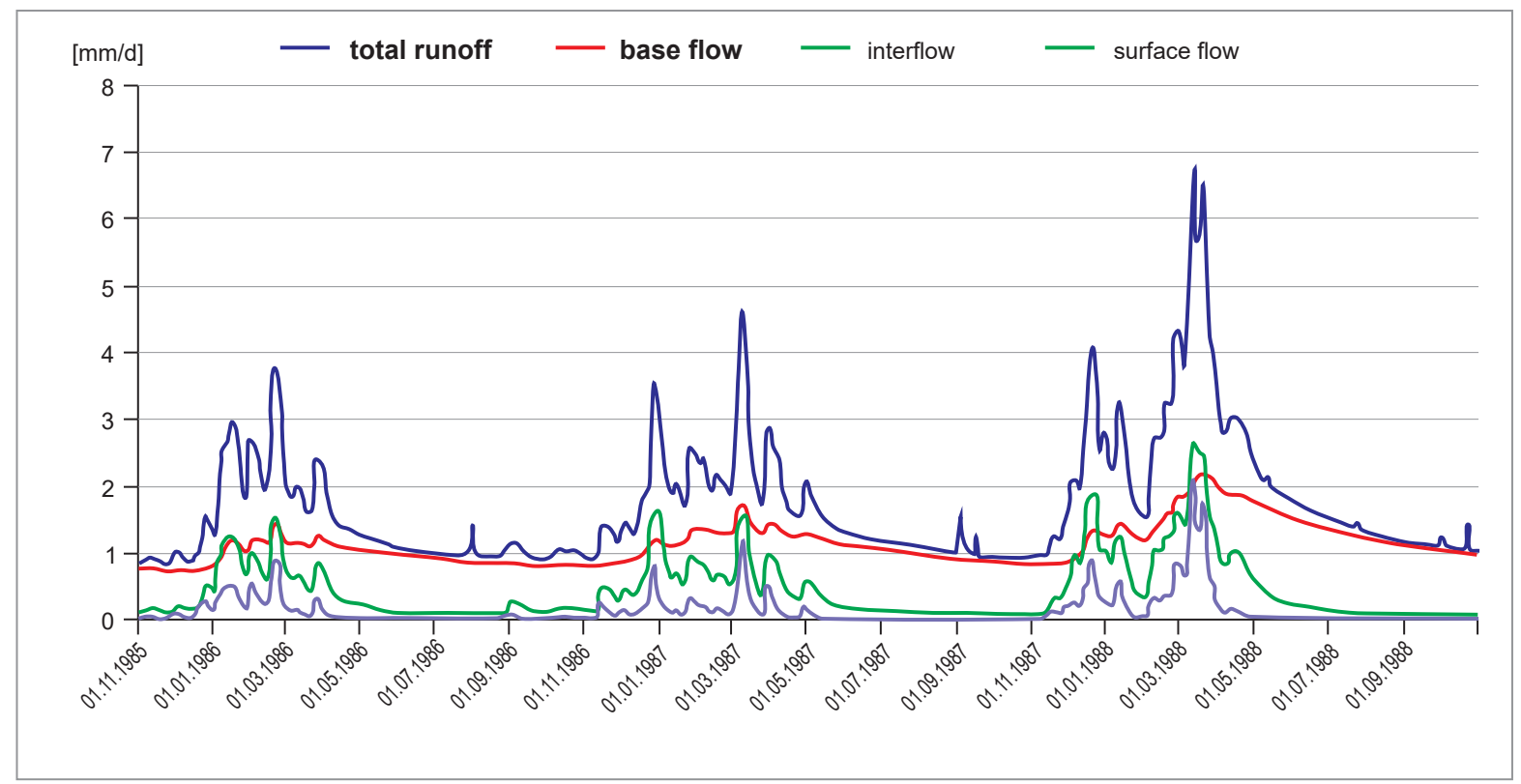

Fig. 11: Modelled total runoff and single discharge components for the base line scenario 
Tab. 8: Water balance components of the three modelled land use scenarios

\begin{tabular}{|c|c|c|c|c|c|}
\hline Water balance component & Scenario & $\begin{array}{c}01.11 .1985- \\
31.10 .1986\end{array}$ & $\begin{array}{c}01.11 .1986- \\
31.10 .1987\end{array}$ & $\begin{array}{c}01.11 .1987- \\
31.10 .1988\end{array}$ & $\begin{array}{c}01.11 .1985 \\
31.10 .1988\end{array}$ \\
\hline Precipitation $[\mathrm{mm} / \mathrm{a}]$ & All & 1398.5 & 1338.1 & 1741.7 & 4478.2 \\
\hline \multirow[t]{3}{*}{ Potential evapotranspiration $[\mathrm{mm} / \mathrm{a}]$} & Base & 1097.4 & 1182.8 & 1193.9 & 3474.1 \\
\hline & Scenario 1 & 1115.4 & 1201.8 & 1212.9 & 3530.1 \\
\hline & Scenario 2 & 1134.7 & 1218.5 & 1231.8 & 3585.0 \\
\hline \multirow[t]{3}{*}{ Real evapotranspiration [mm/a] } & Base & 832.9 & 812.5 & 835.2 & 2480.6 \\
\hline & Scenario 1 & 842.7 & 821.2 & 845.1 & 2508.9 \\
\hline & Scenario 2 & 845.3 & 814.4 & 840.3 & 2500.0 \\
\hline \multirow[t]{3}{*}{ Total runoff $[\mathrm{mm} / \mathrm{a}]$} & Base & 500.2 & 581.0 & 773.8 & 1854.9 \\
\hline & Scenario 1 & 493.5 & 571.3 & 764.1 & 1828.9 \\
\hline & Scenario 2 & 509.1 & 581.6 & 780.2 & 1870.2 \\
\hline \multirow[t]{3}{*}{ Base flow $[\mathrm{mm} / \mathrm{a}]$} & Base & 346.6 & 398.9 & 496.1 & 1241.6 \\
\hline & Scenario 1 & 343.6 & 393.9 & 490.2 & 1228.2 \\
\hline & Scenario 2 & 363.9 & 412.2 & 511.7 & 1287.8 \\
\hline \multirow[t]{3}{*}{ Interflow $[\mathrm{mm} / \mathrm{a}]$} & Base & 124.1 & 146.5 & 209.8 & 480.4 \\
\hline & Scenario 1 & 120.7 & 143.0 & 205.8 & 469.5 \\
\hline & Scenario 2 & 116.1 & 137.1 & 203.1 & 456.4 \\
\hline \multirow[t]{3}{*}{ Surface flow $[\mathrm{mm} / \mathrm{a}]$} & Base & 37.8 & 40.1 & 71.3 & 149.2 \\
\hline & Scenario 1 & 39.0 & 40.6 & 72.1 & 151.7 \\
\hline & Scenario 2 & 34.5 & 35.5 & 67.8 & 137.9 \\
\hline \multirow[t]{3}{*}{ Groundwater recharge $[\mathrm{mm} / \mathrm{a}]$} & Base & 371.5 & 423.1 & 522.6 & 1317.2 \\
\hline & Scenario 1 & 369.3 & 421.6 & 517.9 & 1308.8 \\
\hline & Scenario 2 & 383.3 & 441.2 & 534.6 & 1359.1 \\
\hline
\end{tabular}

components (Tab. 8; Fig. 12) with only small differences in simulation results between the land cover scenarios. The same is true for the discharge volume, which remains nearly identical in the different land use scenarios; there is no shift in the percentage of discharge components either (Tab. 8). In the dry year total runoff decrease slightly in scenario 1 and increase again in scenario 2 due to the change in real evapotranspiration. Only the base flow shows a reaction with increase in scenario 2 compared to scenario 1 and the base line because of the higher groundwater recharge. Although the relative contribution of the discharge components to the runoff volume is independent from land use changes, it corresponds to annual precipitation. The quantities of base flow and interflow increase from the driest to the wettest year for all three scenarios in the same amount (+ $30 \%$, Tab. 8$)$.

\section{Discussion and conclusions}

In this study, the physically based water balance simulation model WaSiM was successfully used to analyse and simulate the water balance of the Rio das Mortes catchment in the Cerrado biome for the first time. This is confirmed by the NASH-Sutcliffe coefficients ( 0.81 for calibration and 0.67 for the validation period) and the simulation of the prevailing discharge dynamics with wet season peaks and dry weather discharge. During model calibration, the simulation of the base flow dynamics at the beginning and in the course of the dry season was particularly difficult. This challenge was solved by using the WaSiM 2D groundwater model and calibrating its parameters specifically. During calibration runs the sensitivity of the parameter of the groundwater model was analysed (Tab. 5). Results shows that 


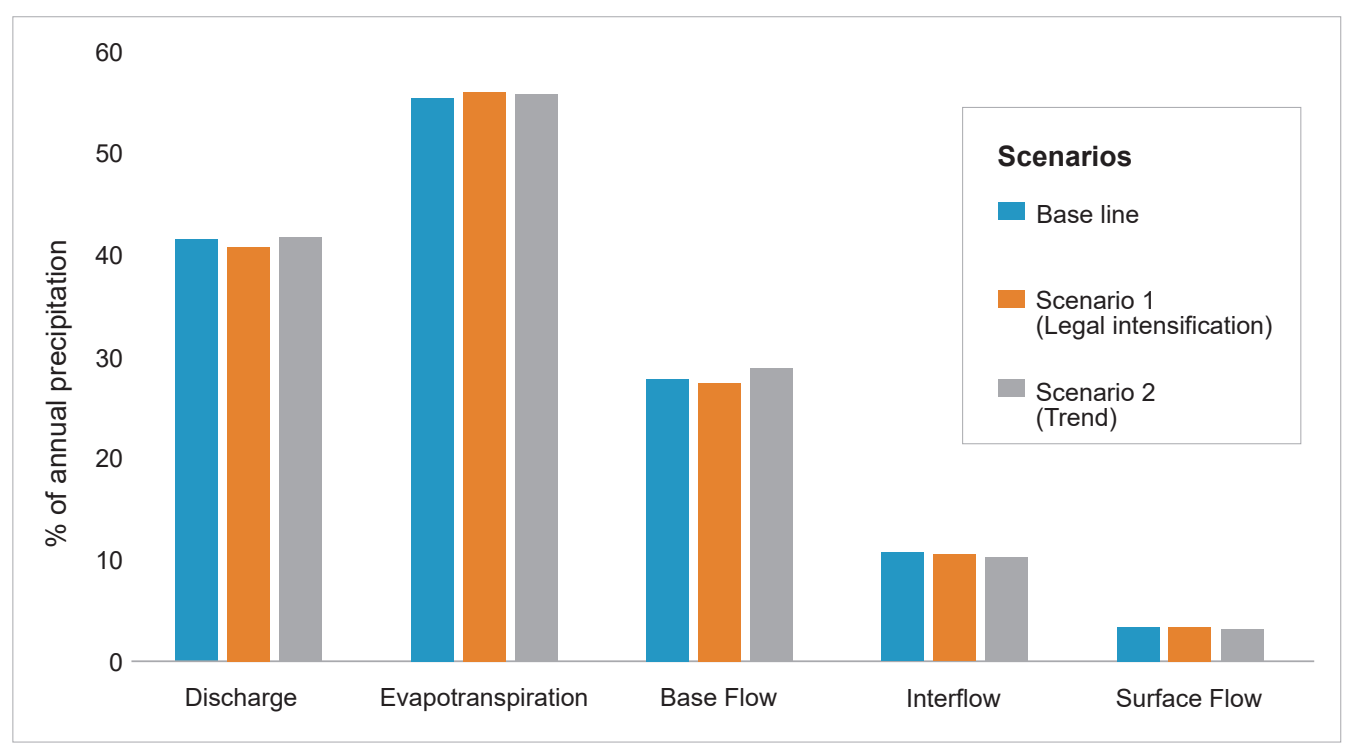

Fig. 12: Annual water balance components in relation to mean annual rainfall for model scenario period 1985-1988

initial groundwater level, groundwater conductivity and flow channel geometry are highly sensitive to flow volume, peak discharge and base flow. Also the conceptual calibration parameters of the unsaturated zone model (drainage density, recession constants of interflow and direct runoff) and the physically based parameters of the soil model $\left(\mathrm{k}_{\mathrm{sat}}\right.$, number and thickness of single soil layers, soil depth) showed a high model sensitivity. Only with these high numbers of successive calibration runs it was possible to simulate the high levels of base flow occurring in the watershed with WaSiM. The immediate increase of base flow in response to the increasing precipitation at the beginning of the rainy season indicates a rapid vertical transport of the incoming water into deeper soil horizons to the groundwater. Since 2012 a well is being monitored in this catchment (Privamera do Leste municipality) by the Geological Survey of Brazil (CPRM, www. http://siagasweb.cprm.gov.br/ layout/index.php). With typical plateau relief and rhodic Ferralsol as soil type (see Fig. 2), Primavera do Leste shows the groundwater level depth ranging between 2-3 $\mathrm{m}$ (Min., rainy season) and 7-8 $\mathrm{m}$ (Max., dry season), which indicate high groundwater recharge and infiltration, confirming modelling results (Tab. 5; Fig. 8). From November 2012 until April 2013 groundwater table rise by $5 \mathrm{~m}$, which explain the rise of base flow from begin until end of the rainy season (cf. Fig. 11).

The adjustment of $k_{\text {sat }}$ values for the main soil types and land use combinations with the calibration runs to the higher values measured in the field during the dry season (Wolf 2016; Fig. 2) contribute to an improved routed discharge with base flow and reasonable groundwater table. The prevailing high levels of base flow throughout the year and the quick reaction of interflow to the high amounts of precipitation at the beginning of the rainy season indicate also a high hydraulic conductivity of the soils and high permeable substrate of the watershed. The literature review by HunKe et al. (2014) determined $k_{\text {sat }}$ values of $102-231 \mathrm{~mm} \mathrm{~h}^{-1}$ for the upper soil horizon of the dominating soil type Latossolo (Ferralsol a. WRB 2014) in the Cerrado Biome.

However, the parameterisation of the soils includes uncertainties due to a lack of consistent information on macropore values and physical soil parameters for soil horizons below $60 \mathrm{~cm}$ depth. The chosen pedotransfer functions for Brazilian soils do not contain estimates or data about the saturated hydraulic conductivity and its change with deforestation or agricultural land use. It is known that the saturated hydraulic conductivity may decrease drastically in response to deforestation (Giambelluca 2002). But the review by Hunke et al. (2014), results from rainfall simulation experiments for erosion modelling by SCHINDEWOLF et al. (2014) on crop and pasture sites on Ferralsol in the upper Rio das Mortes catchment and $k_{\text {sat }}$-measurements by Wolf (2016) and Nobrega et al. (2015) with more than $100 \mathrm{~mm}$ $\mathrm{h}^{-1}$ on pasture and $20 \mathrm{~mm} \mathrm{~h}^{-1}$ on cropland showed that infiltration rates remain high after deforestation. Further, WendLand et al. (2007) report that highest groundwater recharge doubles on pasture and cropland compared to Cerrado. Oliveira et al. (2017) found higher and lower groundwater recharge val- 
ues (maximum) with 43 and $-96 \mathrm{~mm} \mathrm{yr}^{-1}$ for Cerrado "campo limpo" (natural grassland) compared to Cerrado "sensu stricto". The paired catchment study (Cerrado versus pasture) by NóBrega et al. (2015) with an increase of total discharge coefficient from 0.27 to 0.40 and high base flow index of 0.95 underline the subsurface discharge dynamic. The dominant importance of slow discharge components (base flow, interflow) in the catchment correlate with the findings by Lima et al. (2001) for Cerrado with $\leq$ $1 \%$ runoff (overland flow) and $\leq 3 \%$ storm streamflow volume (runoff and quick interflow) for pasture (Nóbrega et al. 2015).

Another uncertainty is the parameterisation of the Cerrado vegetation with distribution of the different Cerrado types and their vegetation parameters (e.g. crown cover, vegetation height, LAI, rooting depth). LAMPARTER et al. (2016) used parameter values for SWAT-modelling based on an extensive new literature analysis. STRAuCH and Volk (2013) showed LAI values for Cerrado ranging between 0.7 and 1.6, which is at the lower end used in WaSiM (Tab. 2). Comparing different methods to estimate ETa for Cerrado vegetation, we see main differences and problems for the dry season with: 0.7 (dry season) -2.7 (wet season) $\mathrm{mm} \mathrm{d}^{-1}$ (STRAUCH and VOLK 2013; MODIS-EVI), 2.3-3.1 $\mathrm{mm} \mathrm{d}^{-1}$ (NóBregA et al. 2017; SEBAL and METRIC models) and 1.9-2.6 mm $\mathrm{d}^{-1}$ (Oliveira et al. 2015; flux tower and MODISEVI). During the rainy season (Nov-April) Eta for cropland is higher as in Cerrado vegetation and pasture (3-5 $\mathrm{mm} \mathrm{d}^{-1}$, Nóbrega et al. 2015; LathuiÈre et al. 2012). Crop evapotranspiration with the main soy bean/corn rotation was calculated with crop coefficients for $651-852 \mathrm{~mm} \mathrm{yr}^{-1}$. Simulated values for ETa by WaSiM with averages for the whole catchment with 1.2-3.1 $\mathrm{mm} \mathrm{d}^{-1}$ and 821-845 $\mathrm{mm} \mathrm{yr}^{-1}$ shows to be similar to these other studies in this region.

Canopy interception was estimated as $4-20 \%$ in the Cerrado vegetation (Oliveira et al. 2015), which indicated that interception loss by WaSiM may be overestimated (see Tab. 2). Moreover, it also has to be considered that the land use change scenario simulations are based on the land use in 2011. As mentioned in the macro-catchment description, $70 \%$ of the watershed was deforested in 2011 and main deforestation occurred before 1985. Considering results by Costa et al. (2003, Rio Tocantins) and CoE et al. (2011, Rio Araguaia), the runoff volume, the surface runoff and the discharge variability were expected to increase by land use change with increase of deforestation. The scenario analysis for the Rio das Mortes watershed indicates that there is only a small difference in runoff volume to the base line. In this analysis, the amount of generated discharge primarily depends on the annual precipitation.

The hydrological soil and substrate characteristics result in an increase of groundwater recharge with scenario 2 in all three years. Conversion of Cerrado to cropland by $20 \%$ of the area should decrease ETa (Tab. 6, literature values), but this is not the case by WaSiM-simulation results. With a better dynamical LAI-approach STRAUCH and VOLK (2013) calculated Cerrado vegetation ETa at $620 \mathrm{~mm}$ per year, which is in the same amount as pasture and less then cropland (Tab. 6). Therefore scenario 2 perhaps showed a slight increase of Eta. A general increase in evapotranspiration for the western part of the Cerrado Biome (Mato Grosso) was determined for the period of 2003-2010 due to the ongoing conversion of pasture land into cropland (soy-corn- rotation) during that period (Oliveira et al. 2014). Simulation results of Scenario 2 also show minimal changes in runoff volume and discharge components. The greatest change is the increase of groundwater recharge, which indicates that the conversion of Cerrado into pasture takes place in predominantly sandy soils (Arenosols) with extremely high infiltration rates (300-400 $\mathrm{mm} \mathrm{h}^{-1}$ Nobrega et al. 2015). The simulated changes in land use, including also an intensification of land use activities, are based on a land cover scenario which is already dominated by agricultural land use. Therefore, the relatively small changes in land use that occur in the two land use scenarios apparently do not have a significant effect on the water balance. Moreover, the greatest land use changes in the catchment already took place before and in the 1980s (SCHLicht 2013). In contrast to the result by Oliveira et al. (2014), previous studies by Costa et al. (2003, Rio Tocantins) and CoE et al. (2011, Rio Araguaia) found an increase in discharge by $24 \%$ (1979-1998) and 25\% (1970-1990) with deforestation in the macro-watersheds. Oliveira et al. (2014) argue that the different sizes of these watersheds may be a reason for these contradictory results and that the response time of watersheds to deforestation is dependent on the scale. In our opinion, the difference of investigated time periods, with 1972/1976 -2012 (Oliveira et al. 2014) and 1979-1998 (Costa et al. 2003), should also be considered in the context of their temporal relationship to the main deforestation phase. As shown for the Rio das Mortes catchment, located in the Rio Tocantins and Araguaia basin, main deforestation occurred before 1990 (Rio Araguaia $56 \%$ in 1990); thus, the main changes in 
water balance components including an increase of discharge took place during the early main phases of deforestation (see CoE et al. 2011; GuzHA et al. 2013). GuZHA et al. (2013) found an increased high and medium discharge in the 1980s, but no similar significant changes in runoff volume, high, medium or low discharge in the adjacent period (Fig. 7). D'AlmeidA et al. (2007) found that there is an increase in discharge 4-5 years after deforestation; it is followed by the establishment of a new equilibrium. With the WaSiM-simulation for a scenario before main deforestation (1977/78) an increase in discharge volume with deforestation could not be observed when comparing scenario simulation (1977/78) with the calibration period (2006-2009). But a shift within the runoff components could be observed, since base flow was much higher and surface runoff much lower before deforestation (WoLF 2016).

The impacts of land use change on the hydrological cycle of a catchment are determined by the size of the deforested area. They can also be seen much earlier and more clearly in small catchments than in large catchments (scale dependency). The paired micro-catchment study by NóBregA et al. (2017) showed an increase by $55 \%$ total discharge between native Cerrado and pasture catchments with similar baseflow indexes. As stated by CostA et al. (2003), the results of studies and modelling approaches that analysed the impacts of land cover changes in large catchments $\left(>100 \mathrm{~km}^{2}\right)$ did not agree with results from meso- or micro-scale analyses (D'Almeida et al. 2007). In contrast to the micro-scale modelling approaches, the large-scale experiments have not always shown an increased annual discharge due to deforestation (COSTA et al. 2003; CoE et al. 2009; DAvidson et al. 2012). Particularly, when modelling large catchments, the effects of land use change on runoff may be hard to discern due to heterogeneous land use, different successional stages of secondary vegetation, spatial variations in precipitation or the appliance of sustainable land management practices in some areas of the macro-catchment (BRUIJNZEEL 2004; Siriwardena et al. 2006).

PANDAY et al. (2015) analysed the deforestation effect for the Xingu river (1970-2000) with separation (simulation results) of land use and climate variability effect on discharge development. There, the climate effect (-82 $\mathrm{mm}$ year ${ }^{-1}$ discharge) masks the land use effect ( $+34 \mathrm{~mm}_{\text {year }}{ }^{-1}$ discharge), so that no clear signal of deforestation exists. In the Cerrado Biome natural vegetation, is drought tolerant and trees are adapted to water scarcity. This means that, in contrast to the rainforest biome of the macro- catchment studies (D'Almeida et al. 2007; Coe et al. 2009; 2011; Costa et al. 2003; Lima et al. 2014), the annual evapotranspiration $(820-990 \mathrm{~mm}$ ) is much lower (Oliveira et al. 2014). Therefore, the water surplus of forest conversion to pasture and crops, which generates a higher discharge, is much smaller.

Modelling results on land use change impacts on the water balance within the Cerrado Biome (Rio das Mortes) show a base flow dominated discharge regime with no reaction on realistically slight land use changes for the future. Main modelling problems results from parameterisation of the ground water model and vegetation parameter, because of scarce information on the aquifer and Cerrado vegetation. Therefore, many calibration runs were necessary to simulate ground water recharge with base flow and the annual climate change with dry and wet season. New results from field measurements with Eddy flux towers in the Cerrado biome (Oliveira et al. 2015) and paired microcatchment water balance indicate, that WaSiM-simulation results are in a realistic range and that future conversion from pasture to crop (land use intensification) can lead to same or even lower discharge, because degraded pasture can have $20 \%$ smaller evapotranspiration (LATHUILLIÈRE et al. 2012) Without atmospheric feedback (rainfall), with maintenance of Cerrado conservation areas and conversion from pasture to crop further changes in land cover can have only a small effect on discharge generation.

\section{Acknowledgements}

This research was feasible thanks to the support of the German Federal Ministry of Education and Research (BMBF) through their funding of the Carbiocial project (www.carbiocial.de). The authors also acknowledge the Fundação de Amparo à Pesquisa do Estado de Mato Grosso (FAPEMAT) and the Brazilian National Council for Scientific and Technological Development (CNPq) for project funding of Brazilian counterpart UFMT (FAMEV).

\section{References}

Allen, R. G.; Pereira, L. S.; Raes, D. and Smith, M. (1998): Crop evapotranspiration - guidelines for computing crop water requirements. FAO Irrigation and drainage paper 56, Rome.

ANA.(Agência Nacional das Águas) (2015). Hidroweb - Dados Convencionais. http://www.snirh.gov.br/hidroweb/ 
Andersen, J.; Refsgantd, J. C. and Jensen, K. H. (2001): Distributed hydrological modeling of the Senegal River Basin - model construction and validation. In: Journal of Hydrology 247, 200-214. https://doi.org/10.1016/ S0022-1694(01)00384-5

Andrade, R. G.; Teixeira, A. H. de C.; Sano, E. E.; Leivas, J. F.; Victoria, D. DE C. and Nogueira, S. F. (2014): Pasture evapotranspiration as indicators of degradation in the Brazilian Savanna. A case study for Alto Tocantins watershed. In: Remote Sensing for Agriculture, Ecosystems and Hydrology XVI, 1-7. https://doi. org/10.1117/12.2067225

Arvor, D.; Meirelles, M.; Dubreuil, V.; Bégué, A. and Shimabukuro, Y. E. (2012): Analyzing the agricultural transition in Mao Grosso, Brazil, using satellite-derived indices. In: Applied Geography 32, 702-713. https:// doi.org/10.1016/j.apgeog.2011.08.007

AYlWARD, B. (2005): Land use, hydrological function and economic value. In: Bonell, M. and Brujnzzeel, L. A. (eds.): Forests, water and people in the humid tropics. Past, present and future hydrological research for integrated land and water management. Cambridge, 99-120. https:// doi.org/10.1017/CBO9780511535666.012

Beuchle, R.; Grecchi, R. C.; Shimabukuro, Y. E.; Seliger, R.; Eva, H. D.; Sano, E. and Achard, F. (2015): Land cover changes in the Brazilian Cerrado and Caatinga biomes from 1990 to 2010 based on a systematic remote sensing sampling approach. In: Applied Geography 58, 116-127. https://doi.org/10.1016/j.apgeog.2015.01.017

Birkinshaw, S. J.; Bathurst, J. C.; Iroumé, A. and Palacois, H. (2011): The effect of forest cover on peak flow and sediment discharge - an integrated field and modelling study in central-southern Chile. In: Hydrological Processes 25 (8), 1284-1297. https://doi.org/ 10.1002/hyp.7900

Bonelt, M. (2005): Runoff generation in tropical forests. In: Bonell, M. and Brujjnzeel, L. A. (eds.): Forests, water and people in the humid tropics. Past, present and future hydrological research for integrated land and water management. Cambridge, 314-406. https://doi. org/10.1017/cbo9780511535666.020

Breuer, L.; Eckhardt, K. and Frede, H.-G. (2003): Plant parameter values for models in temperate climates. In: Ecological Modelling, 169, 237-293. https://doi. org/10.1016/s0304-3800(03)00274-6

BruijnzeEL, L. A. (2004): Hydrological functions of tropical forests: not seeing the soil for the trees? In: Agriculture, Ecosystems and Environment 104, 185-228. https:// doi.org/10.1016/j.agee.2004.01.015

Brutsaert, W. (2005): Hydrology. An Introduction. Cambridge.

Canadell, J.; Jackson, R. B.; Ehleringer, J. R.; Mooney, H. A.; SAla, O. E. and Schulze, E.-D. (1996): Maximum rooting depth of vegetation types at the global scale.
In: Oecologia 108, 583-595. https://doi.org/10.1007/ bf00329030

Carsel, R. F. and Parrish, R. S. (1988): Developing joint probability distributions of soil water retention characteristics. In: Water Resource Research 24, 755-769. https://doi.org/10.1029/wr024i005p00755

Castro, E. A. De and Kauffman, J. B. (1998): Ecosystem structure in the Brazilian Cerrado: a vegetation gradient of aboveground biomass, root mass and consumption by fire. In: Journal of Tropical Ecology 14, 263-283. https://doi.org/10.1017/s0266467498000212

Coe, M. T.; Costa. M. H. and Sonres-Filho, B. S. (2009): The influence of historical and potential future deforestation on the stream flow of the Amazon River - Land surface processes and atmospheric feedbacks. In: Journal of Hydrology 369, 165-174. https://doi. org/10.1016/j.jhydrol.2009.02.043

Coe, M. T.; Latrubesse, E. M.; Ferreira, M. E. and Amsler, M. L. (2011): The effects of deforestation and climate variability on the stream flow of the Araguaia River, Brazil. In: Biogeochemistry 105, 119-131. https://doi. org/10.1007/s10533-011-9582-2

Costa, M. H. (2005): Large-scale hydrological impacts of tropical forest conversion. In: BONELL, M. and BRUIJNZEEL, L. A. (eds.): Forests, water and people in the humid tropics. Past, present and future hydrological research for integrated land and water management. Cambridge, 590-597. https://doi.org/10.1017/ cbo9780511535666.030

Costa, M. H.; Botta, A. and Cardille, J. A. (2003): Effects of large-scale changes in land cover on the discharge of the Tocantins River, Amazonia. In: Journal of Hydrology 283, 206-217. https://doi.org/10.1016/s00221694(03)00267-1

Coy, M. and Klingler, M. (2014): Frentes pioneiras em transformação: O eixo da BR-163 e os desafios socioambientais. In: Revista Territórios e Fronteiras 7 (1), 1-26. https://doi.org/10.22228/rt-f.v7i0.282

CPRM (Serviço Geológico do Brasil): http://siagasweb. cprm.gov.br/layout/index.php

D`Almeida, C.; Vörösmarty, C. J.; Marengo, J. A.; Hurtt, G. C.; Dingman, S. L. and Keim, B. D. (2007): The effects of deforestation on the hydrological cycle in Amazonia: a review on scale and resolution. In: International Journal of Climataology 27, 633-647. https://doi. org/10.1002/joc. 1475

Davidson, E. A.; de Araújo, A. C.; Artaxo, P.; Balch, J. K.; Foster Brown, I.; Bustamante, M. M. C.; Coe, M. T.; DeFries, R. S.; Keller, M.; Longo, M.; Munger, J. W.; Schroeder, W.; Soares-Filho, B. S.; Souza Jr, C. M. and Wofsy, S. C. (2012): The Amazon basin in transition. In: Nature 481, 321-328. https://doi.org/10.1038/nature10717 
DeFries, R.; Herold, M.; Verchot, L.; Macedo, M. N. and Shimabukuro, Y. (2013): Export-oriented deforestation in Mato Grosso: harbinger or exception for other tropical forests? In: Philosophical Transactions of the Royal Society 368, 1-8. https://doi.org/10.1098/rstb.2012.0173

Drigo, R. (2005): Trends and patterns of tropical land use change. In: Bonell, M. and Bruijnzeel, L. A. (eds.): Forests, water and people in the humid tropics. Past, present and future hydrological research for integrated land and water management. Cambridge, 9-39. https:// doi.org/10.1017/cbo9780511535666.006

Eckhardt, K.; Breuer, L. and Frede, H. G. (2003): Parameter uncertainty and the significance of simulated land use change effects. In: Journal of Hydrology 273, 164 176. https://doi.org/10.1016/s0022-1694(02)00395-5

Elfert, S. and Bormann, H. (2010): Simulated impact of past and possible future land use changes on the hydrological response of the Northern German lowland 'Hunte' catchment. In: Journal of Hydrology 383, 245255. https://doi.org/10.1016/j.jhydrol.2009.12.040

EMBrapa (2012): O Cerrado. http://www.cpac.embrapa.br/ unidade/ocerrado/

Fearnside, P. M.; Righi, C. A.; Lima de Alencastro GraÇa, P. M.; Keizer, E. W. H.; Cerri, C. C.; Nogueira, E. M. and BarbozA, R. I. (2009): Biomass and greenhouse-gas emissions from land-use change in Brazil's Amazonian "arc of deforestation": the states of Mato Grosso and Rondônia. In: Forest Ecology and Management 258, 1968-1978. https://doi.org/10.1016/j. foreco.2009.07.042

Ferreira, L. G.; Yoshioka, H.; Huete, A. and Sano, E. E. (2004): Optical characterization of the Brazilian Savanna physiognomies for improved land cover monitoring of the cerrado biome: preliminary assessments from an airborne campaign over an LBA core site. In: Journal of Arid Environments 56, 425-447. https://doi. org/10.1016/s0140-1963(03)00068-5

Germer, S.; Neill, C.; Veter, T.; Chaves, J.; Krusche, A. V. and ElsenbeER, H. (2009): Implications of long-term land-use change for the hydrology and solute budgets of small catchments in Amazonia. In: Journal of Hydrology 364, 349-363. https://doi.org/10.1016/j.jhydrol.2008.11.013

Gerold, G. (2012): Wasserhaushalt in Regenwaldeinzugsgebieten - regionale Folgen von Landnutzungsänderung und „climate change“. In: Fassmann, H. and Glade, T. (eds.): Geographie für eine Welt im Wandel. 57. Deutscher. Geographentag in Wien. Vienna, 255-281.

Giambelluca, T. W. (1996): Tropical land cover change. Characterising the post-forest land surface. In: GIAmBelluca, T. W. and Henderson-Sellers, A. (1996): Developing southern hemisphere perspectives. Chichester, 293-318.
Giambelluca, T. W. (2002): Hydrology of altered tropical forest. In: Hydrological Processes 16, 1665-1669. https://doi.org/10.1002/hyp.5021

Gollnow, F.; Göpel, J.; de Barros Viana Hissa, L.; SchalDACH, R. and LAKES, T. (2017): Scenarios of land-use change in a deforestation corridor in the Brazilian Amazon: combining two scales of analysis. Regional Environmental Change, 1-17. https://doi.org/10.1007/ s10113-017-1129-1

Grip, H.; Fritsch, J. M. and Bruijnzeel, L. A. (2005): Soil and water impacts during forest conversion and stabilisation to new land use. In: Bonell, M. and Bruijnzeel, L. A. (eds.): Forests, water and people in the humid tropics. Past, present and future hydrological research for integrated land and water management. Cambridge, 561589. https://doi.org/10.1017/cbo9780511535666.029

GrÜnING, M. (2014): Pedohydrologischer Vergleich dreier Kleinsteinzugsgebiete mit unterschiedlicher Landnutzung (Cerradovegetation, Weide, Soja/Mais-Anbau) in der Cerradoregion Zentralbrasiliens (Cuiabá). MSc Thesis. Göttingen.

GÜNTNER, A. (2002): Large-scale hydrological modelling in the semi-arid North-East of Brazil. PhD thesis. Potsdam.

Guzha, A. C.; Nóbrega, R.; Kovacs, K.; Amorim, R. S. S. and Gerold, G. (2014): Quantifying impacts of agroindustrial expansion in Mato Grosso, on watershed hydrology using the soil and water assessment tool (SWAT) model. Proceedings of the $20^{\text {th }}$ International Congress on Modelling and Simulation, Adelaide, Australia, 1-6 December 2013. Adelaide, 1833-1839.

Guzha, A. C.; Nóbrega, R.; Santos, C. A. G. and GerOLD, G. (2013): Investigating discharge and rainfall variability in an Amazonian watershed: do any trends exist? In: Climate and land surface changes in hydrology. Proceedings of H01, IAHS-IAPSO-IASPEI Assembly, Gothenburg, Sweden, July 2013. IAHS Publ. 359, 346-351.

Hölscher, D.; Mackensen, J. and Roberts, J. M. (2005): Forest recovery in the humid tropics. changes in vegetation structure, nutrient pools and the hydrological cycle. In: Bonell, M. and Brujjnzeel, L. A. (eds.): Forests, water and people in the humid tropics. Past, present and future hydrological research for integrated land and water management. Cambridge, 598-621. https://doi.org/10.1017/CBO9780511535666.031

Hunke, P.; Mueller, E. N.; Schröder, B. and Zeilhofer, P. (2014): The Brazilian Cerrado: assessment of water and soil degradation in catchments under intensive agricultural use. In: Ecohydrology 8, 1154-1180. https:// doi.org/10.1002/eco.1573

Jansson, P.-E. and Karlberg, L. (2001): Coupled heat and mass transfer model for soil-plant-atmosphere systems. Stockholm. 
KLeinhans, A. (2004): Einfluss der Waldkonversion auf den Wasserhaushalt eines tropischen Regenwaldeinzugsgebietes in Zentral Sulawesi (Indonesien). PhD thesis. Göttingen.

KÖRNER, C. (1994): Leaf diffusive conductances in the major vegetation types of the globe. In: Schulze, E. D. and. Caldwell, M. M (eds): Ecophysiology of photosynthesis. Berlin, 463-490.

Lamparter, G.; Nóbrega, R.. L. B.; Kovacs, K.; Amorim, R. S. and Gerold, G. (2016): Modelling hydrological impacts of agricultural expansion in two macro-catchments in Southern Amazonia, Brazil. In: Regional Environmental Change. https://doi.org/10.1007/s10113016-1015-2

LAndon, J. R. (1984): Booker tropical soil manual. A handbook for soil survey and agricultural land evaluation in the tropics and subtropics. New York.

Lapola, D. M.; Martinelli, L. A.; Peres, C. A.; Ometto, J. P. H. B.; Ferreira, M. E.; Nobre, C. A.; Aguiar, A. P. D.; Bustamante, M. M. C.; Cardoso, M. F.; Costa, M. H.; Joly, C. A.; Leite, C. C.; Moutinho, P.; Sampaio, G.; Strassburg, B. B. N. and Vieira, I. C. G. (2014): Pervasive transition of the Brazilian land-use system. In: Nature Climate Change 4, 27-35. https://doi. org/10.1038/nclimate2056

Lathuillière, M. J.; Johnson, M. S. and Donner, S. D. (2012): Water use by terrestrial ecosystems: temporal variability in rainforest and agricultural contributions to evapotranspiration in Mato Grosso, Brazil. In: Environmental Research Letters 7, 1-12. https://doi. org/10.1088/1748-9326/7/2/024024

LeEmhuis, C. (2005): The impact of El Niño Southern Oscillation events on water resource availability in Central Sulawesi, Indonesia. A hydrological modelling approach. $\mathrm{PhD}$ thesis. Göttingen.

Lilienfein, J.; Wilcke, W.; Vilela, L.; Ayarza, M. A.; dO Carmo Lima, S. and ZECH, W. (2003): Soil fertility under native Cerrado and pasture in the Brazilian savanna. In: Soil Science Society of America Journal 67 (4), 11951205. https://doi.org/10.2136/sssaj2003.1195

Lima, J. E.F. W.; DA Silva, C. L. and Oliveira, C. A. DA S. (2001): Comparacao da evapotranspiracao real simulada e observada em uma bacia hidrográfica em condicoes naturais de cerrado. In: Revista Brasileira de Engenharia Agrícola e Ambiental 5 (1), 33-41. https://doi. org/10.1590/S1415-43662001000100007

Lima, L. S.; Coe, M. T.; Soares Filho B. S.; Cuadra, S. V.; Dias, L. C. P.; Costa, M. H.; Lima, L. S. and Rodriguez, H. O. (2014): Feedbacks between deforestation, climate, and hydrology in the Southwestern Amazon: implications for the provision of ecosystem services. In: Landscape Ecology 29, 261-274. https://doi.org/10.1007/ s10980-013-9962-1
Macedo, M. N.; DeFries, R. S.; Morton, D. C.; StickLer, C. M.; Galford, G. L. and Shimanukuro, Y. E. (2012): Decoupling of deforestation and soy production in the Southern Amazon during the late 2000s. In: PNAS 109 (4), 1341-1346. https://doi.org/10.1073/ pnas.1111374109

Malhi, Y.; Roberts, J. T.; Betts, R. A.; Killeen, T. J.; Li, W. and Nobre, C. A. (2008): Climate change, deforestation, and the fate of the Amazon. In: Science 319, 169-172. https://doi.org/10.1126/science.1146961

Meister, S. (2014): Modelling land use change impacts on the water balance of the Rio das Mortes macro-catchment using WaSiM. MSc thesis.Göttingen.

MMA (Ministério do Meio Ambiente) (2009): Relatório técnico de monitoramento de dematamento no bioma cerrado, 2002 a 2008. Dados revisados. http://www. mma.gov.br/estruturas/sbf_chm_rbbio/_arquivos/relatorio_tecnico_monitoramento_desmate_bioma_cerrado_csr_rev_72_72.pdf

- (2011): Monitoramento do desmatamento nos biomas brasileiros por satellite - Monitoramento do bioma cerrado 2009-2010. http://www.mma.gov.br/estruturas/sbf_chm_rbbio/_arquivos/relatoriofinal_cerrado_2010_final_72_1.pdf

Montgomery, R. F. and Askew, G. P. (1983): Soils of tropical savannas. In: Bourliére, F. (ed): Ecosystems of the world, Vol. 13 - Tropical Savannas. Amsterdam, 63-78.

Müller, H.; Rufin, P.; Griffiths, P.; Barros Siquieira, A. J. and Hostert, P. (2014): Mining dense Landsat time series for separating cropland and pasture in a heterogeneous Brazilian savanna landscape. In: Remote Sensing of Environment 156, 490-499. https://doi. org/10.1016/j.rse.2014.10.014

Nash, J. E. and Sutcliffe, J. V. (1970): River flow forecasting through conceptual models, Part I - a discussion of principles. In: Journal of Hydrology 10. 282-290. https://doi.org/10.1016/0022-1694(70)90255-6

Nepstad, D.; Soares-Filho, B. S.; Merry, F.; Lima, A.; Moutinho, P.; Carter, J.; Bowman, M.; Cattaneo, A.; Rodrigues, H.; Schwartzman, S.; McGrath, D. G.; Stickler, C. M.; Lubowski, R.; Piris-Cabezas, P.; Rivero, S.; Alencar, A.; Almeida, O. and Stella, O. (2009): The end of deforestation in the Brazilian Amazon. In: Science 326, 1350-1351. https://doi.org/10.1126/science.1182108

Nepstad, D.; McGrath, D.; Stickler, C.; Alencar, A.; Azevedo, A.; Swette, B.; Bezerra, T.; Digiano, M.; Shimada, J.; Seroa da Motta, S.; Armijo, E.; Castello, L.; Brando, P.; Hansen, M. C.; McGrath-Horn, M.; Carvalho, O. and Hess, L. (2014): Slowing Amazon deforestation through public policy and interventions in beef and soy supply chains. In: Science 334 (6118), 1118-1123. https://doi.org/10.1126/science. 1248525 
NieHoff, D. (2001): Modellierung des Einflusses der Landnutzung auf die Hochwasserentstehung in der Mesoskala. PhD thesis. Potsdam.

Nóbrega, R. L. B.; Guzha, A. C.; Torres, G. N.; Kovacs, K.; Lamparter, G.; Amorim, R. S. S.; Couto, E. and GerOLD, G. (2015): Identifying hydrological responses of micro-catchments under contrasting land use in the Brazilian Cerrado. In: Hydrology and Earth System Sciences Discussion 12, 9915-9975. https://doi.org/10.5194/ hessd-12-9915-2015, 2015

- (2017): Effects of conversion of native cerrado vegetation to pasture on soil hydro-physical properties, evapotranspiration and streamflow on the Amazonian agricultural frontier. In: PLoS ONE. https://doi.org/10.1371/journal.pone.0179414

Oliveira, P. T. S.; Nearing, M. A.; Susan Moran, S.; Goodrich, D. C.; Wendland, E. and Gupta, H. V. (2014): Trends in water balance components across the Brazilian Cerrado. In: Water Resources Research 50 (9), 7100_ 7114. https://doi.org/10.1002/2013WR015202

Oliveira, P. T. S.; Wendland, E.; Nearing, M. A.; Scott, R. L.; Rosolem, R. and Rocha, H. R. DA (2015): The water balance components of undisturbed tropical woodlands in the Brazilian cerrado. In: Hydrolology and Earth System Sciiences 19, 2899-2910. https://doi.org/10.5194/ hess-19-2899-2015

Oliveira, P. T. S.; Leite, M. B.; Mattos, T.; Nearing, M. A.; Scott, R. L.; Xavier, R. De O.; Matos, D. M. Da S. and Wendland, E. (2017): Groundwater recharge decrease with increased vegetation density in the Brazilian Cerrado. In: Ecohydrology 10 (1). https:/ / doi.org/10.1002/eco.1759

Panday, P. K.; Coe, M. T.; Macedo, M. N.; Lefebvre, P. and de Almeida Castanho, A. D. (2015): Deforestation offsets water balance changes due to climate variability in the Xingu River in eastern Amazonia. In: Journal of Hydrology 523, 822-829. https://doi.org/10.1016/j. jhydrol.2015.02.018

Piao, S.; Friedlingstein, P.; Ciais, P.; De Noblet-Ducoudre, N.; Labat, D. and Zaehle, S. (2007): Changes in climate and land use have a larger direct impact than rising CO2 on global river runoff trends. In: PNAS 104, 15242 15247. https://doi.org/10.1073/pnas.0707213104

Projeto RADAMBRASIL, 1973-1986. Levantamento de Recursos Naturais. Vol. 1-33 (In Portuguese), Dept. Nacional de Producao Mineral, Rio de Janeiro

Richards, L. A. (1931): Capillary conduction of liquids through porous media. In: Journal of Applied Physics $1,318-333$.

Rieger, W. (2012): Prozessorientierte Modellierung dezentraler Hochwasserschutzmaßnahmen. PhD thesis. Munich.

Rieger, W.; Winter, F. and Disse, M. (2010): Uncertainties of soil parameterisation in process-based simulation of distributed flood control measures. In: Advances on Geosciences 27, 121-129. https://doi.org/10.5194/adgeo-27-121-2010

Sano, E. E.; Rosa, R.; Silva Brito, J. L. and Guimarães FerREIRA, L. (2008): Mapeamento semidetalhado do uso de terra do Bioma Cerrado. Notas Científicas. In: Pesquisa agropecuária brasileira 43 (1), 153-156. https://doi. org/10.1590/S0100-204X2008000100020

Schaldach, R.; Göpel, J. and Klingler, M. (2017): The role of future land-use change in Southern Amazonia to reach the aims of Brazil's National Climate Plan. In: Erdkunde, 71 (3), 213-230. https://doi.org/10.3112/ erdkunde.2017.03.04

Schindewolf, M.; SchÖnke, D.; Amorim, R. S. S. and Schmidt, J. (2014): Effects of contour banks and notill measures on run-off and sediment yield in Campo Verde region, Mato Grosso. In: Gerold, G.; Jungkunst, H.; Wantzen, K. M.; Schönenberg, R.; Amorim, R. S. S.; Couto, E. G.; Madari, B. and Hohnwald, S. (eds): Interdisciplinary analysis and modeling of carbon-optimized land management strategies for Southern Amazonia. Göttingen, 85-100.

Schlicht, S. (2013): Dynamics of deforestation and agricultural production in the upper Rio das Mortes watershed in Mato Grosso state (Brazil). MSc. thesis. Göttingen.

Schulla, J. (1997): Hydrologische Modellierung von Flussgebieten zur Abschätzung der Folgen von Klimaänderungen. $\mathrm{PhD}$ thesis. Zurich.

- (2013): Model Description WaSiM. http://www.wasim. $\mathrm{ch} /$ de/products/wasim_description.htm

Schulla, J. and Jasper, K. (2007): Model description WaSiMETH. http://www.wasim.ch/de/products/wasim_description.htm (02.07.2017)

Siriwardena, L.; Finlayson, B. L. and McMahon, T. A. (2006): The impact of land use change on catchment hydrology in large catchments. The Comet River, Central Queensland, Australia. In: Journal of Hydrology 326, 199-214. https://doi.org/10.1016/j.jhydrol.2005.10.030

Strauch, M. and VolK, M. (2013): SWAT plant growth modification for improved modeling of perennial vegetation in the tropics. In: Ecologoical Modelling 269, 98-112. https://doi.org/10.1016/j.ecolmodel.2013.08.013

Tomasella, J.; Hodnett, M. G. and Rossato, L. (2000): Pedotransfer functions for the estimation of soil water retention in Brazilian soils. In: Soil Science Society of America Journal 64 (1), 327-338. https://doi. $\mathrm{org} / 10.2136 /$ sssaj2000.641327x

UFV (Universidade Federal de Viçosa) (no year/a): Cerrado. ftp.//www.ufv.br/def/disciplinas/ENF448/aula_10_fitogeografia/BIOMAS/CERRADO.pdf

- (no year/b): A Caracterização do Cerrado. ftp.//www.ufv. br/dns/NUT392/CERRADO.DOC 
van den Berg, M.; Klamt, E.; van Reeuwijk, L. P. and Sombeck, W. G. (1997): Pedotransfer functions for the estimation of moisture retention characteristics of Ferralsols and related soils. In: Geoderma 78, 161-180. https://doi.org/10.1016/s0016-7061(97)00045-1

van Genuchten, M. T. (1980): A closed-form equation for predicting the hydraulic conductivity of unsaturated soils. In: Soil Science Society of America Journal 44, 891-898. https://doi.org/10.2136/ sssaj1980.03615995004400050002x

Vertessy, R. A. and Elsenbeer, H. (1999): Distributed modeling of storm flow generation in an Amazonian rainforest catchment. Effects of model parameterization. In: Water Resources Research 35, 2173-2187. https://doi. org/10.1029/1999WR900051

Wendland, E.; Barreto, C. and Gomes, L. H. (2007): Water balance in the Guarani Aquifer outcrop zone based on hydrogeologic monitoring. In: Journal of Hydrology 342, 261-269. https://doi.org/10.1016/j.jhydrol.2007.05.033

Weynants, M. Vereecken, V. and Javaux, M. (2009): Revisiting Vereecken pedotransfer functions. Introducing a closed-form hydraulic model. In: Vadose Zone Journal 8, 86-95. https://doi.org/10.2136/vzj2008.0062

Wolf, R. (2016): Process-based hydrological modeling of the Rio das Mortes catchment based on field and laboratory experiments. MSc thesis. Munich.

Wösten, J. H. M.; Lilly, A.; Nemes, A. and Le Bas, C. (1999): Development and use of a database of hydraulic properties of European soils. In: Geoderma 90, 169185. https://doi.org/10.1016/s0016-7061(98)00132-3

\section{Authors}

Sarina Meister Rodolfo Nobrega Prof. Dr. Gerhard Gerold

Department of Landscape Ecology Faculty of Geoscience and Geography Georg-August University of Göttingen

Goldschmidtstraße 3 37077 Göttingen Germany smeiste@gwdg.de rodolfo.nobrega@geo.uni-goettingen.de ggerold@gwdg.de

Dr. Wolfgang Rieger Ronja Wolf

Chair of Hydrology and River Basin Management

Department of Civil

Geo and Environmental Engineering

Technical University of Munich

Arcisstr. 21

80333 Munich

Germany

wolfgang.rieger@tum.de 